\title{
27. VOLCANIC EVOLUTION OF GRAN CANARIA RECONSTRUCTED FROM APRON SEDIMENTS: SYNTHESIS OF VICAP PROJECT DRILLING ${ }^{1}$
}

\author{
Hans-Ulrich Schmincke ${ }^{2}$ and Mari Sumita ${ }^{2}$
}

\begin{abstract}
The ages, types, and compositions of volcaniclastic sediments, physical properties, and downhole logs obtained during Leg 157 drilling at Sites 953 and 954 north and 955 and 956 south of Gran Canaria, with a cumulative penetration of almost $3000 \mathrm{~m}$ and an overall recovery rate of $75 \%$, correlate well compositionally and stratigraphically to major volcanic and nonvolcanic phases on the island. Volcaniclastic sediment contributions from neighboring islands are volumetrically insignificant.

The highest rate of volcaniclastic sedimentation (>150 m/m.y.) corresponds to the middle Miocene basaltic late seamount stage of Gran Canaria, the lowermost deposits drilled being thick, graded, hyaloclastite tuffs and debris flows, dominated by poorly vesiculated, altered sideromelane clasts, suggesting eruption at a water depth of more than $500 \mathrm{~m}$. Large basalt clasts, some of subaerial origin, at the base of the strongly graded deposits suggest synchronous subaerial activity. A lithic-rich debrisflow deposit (Site 956), at least $80 \mathrm{~m}$ thick, is interpreted to have been generated by a major collapse of southwestern Gran Canaria, thereby triggering tsunami waves, whose deposits are now represented by $2 \mathrm{~m}$ of amphibole, phlogopite, apatite, and Cr-spinel-rich sandstones overlying the debrite.

Breccias, lapillistones, and tuffs containing vesicular shards record the transition from shallow submarine to emergent environment. The erosion of the older subaerial shield basalts in eastern Gran Canaria is reflected in hundreds of thin, fine-grained turbidites at Site 953, whereas submarine activity continued in the southwest (Site 956). Nearly identical Nb: $\mathrm{Zr}$ and Nb:Y ratios in all submarine and subaerial basalts suggest fairly constant source conditions.

A precisely dated $(13.9 \mathrm{Ma})$ rhyolitic to basaltic syn-ignimbrite turbidite separates the basal hyaloclastites at three sites from 50- to 10-m-thick, dominantly rhyolitic volcaniclastic turbidite series correlated to the Mogán Group (14-13.3 Ma) and 130- to 250-m-thick, dominantly trachyphonolitic volcaniclastic turbidite sections correlated to the Fataga Group (13.3-9.5 Ma). Near-unique mineral phases or assemblages, glass, feldspar, amphibole and clinopyroxene, and bulk-rock compositions represent robust criteria for unequivocally correlating at least seven syn-ignimbrite volcaniclastic turbidites between three sites, which are $160 \mathrm{~km}$ (Sites 953 and 956) and $170 \mathrm{~km}$ (Sites 953 and 955) apart from each other. Syn-ignimbrite turbiditic tuffs and lapillistones are characterized by brown angular glass shards, of strongly welded tuff, interpreted to have been generated when hot ash flows entered the sea. They quickly welded and were fragmented by quench granulation and steam explosions. Synignimbritic depositional units are as much as $2 \mathrm{~m}$ thick and many consist of a coarse-grained, massive graded basal part containing shallow-water faunal debris overlain by thin turbidites of fine-grained vitric ash, dominantly reflecting low-density waning turbidites. Broad concentric deposition of turbidites south of the island contrasts with the more channelized sediment transport off northeastern Gran Canaria. Tholeiitic to alkali basaltic, blocky, fresh sideromelane shards in many volcaniclastic turbidites are interpreted to represent the parent magmas to the rhyolites and phonolites and to have been erupted on the lower submarine flanks below the level of the low-density magma column.

At all four sites, the accumulation, rate based on integrated bio-and magnetostratigraphy, is at a minimum $(<\sim 20 \mathrm{~m} / \mathrm{m} . \mathrm{y}$.) during the major nonvolcanic phase on Gran Canaria between $\sim 9$ and $5 \mathrm{Ma}$. This clearly indicates that the rate of supply of volcanogenic sediment to the apron closely corresponds in time to major volcanic phases. Major debris avalanches generated by collapse of the Pliocene Roque Nublo stratocone occur as coarse breccias at Holes 953C, 954B, and 956B. Erosion differed significantly throughout the entire 16-m.y. history of the island between the wind-exposed, more strongly eroded northern vs. the dry, leeward southern side of the island, and this is reflected in the higher abundance of epiclastic sediments at Site 953.

Pleistocene trachytic to phonolitic ash layers reflect many more explosive phases of the Las Cañadas volcanic complex on the island of Tenerife than those preserved on land. A shift with time toward more silica-undersaturated composition is interpreted as a change toward lower degrees of partial melting.

The sediment supply to the sediment basins north and south of the island differed drastically because post-Miocene volcanic activity was almost completely absent in southern Gran Canaria. The sediment supply from Africa was almost completely restricted to the apron south of the island because the east Canary Ridge prevented transport to the west. High alkalinity in the absence of significant organic matter diagenesis and high magnesium and lithium contents in the $\mathrm{CO}_{2}$-charged pore waters at Site 954, the drill site closest to the island, are explained by the proximity to the belt of Holocene mafic volcanism in northern Gran Canaria.
\end{abstract}

\section{INTRODUCTION}

Ocean islands are systems in which the growth of the islands, a result of mantle processes, and their degradation by mass wasting are intimately interwoven. The role of ocean islands as sediment sources was not appreciated until Menard (1956) introduced the concept of

${ }^{1}$ Weaver, P.P.E., Schmincke, H.-U., Firth, J.V., and Duffield, W. (Eds.), 1998. Proc. ODP, Sci. Results, 157: College Station, TX (Ocean Drilling Program).

${ }^{2}$ GEOMAR Forschungszentrum, Wischhofstraße 1-3, D-24148, Kiel, Federal Republic of Germany. hschmincke@geomar.de archipelagic aprons surrounding ocean islands, deduced from bathymetry and seismic data. Menard argued that the volume of lavas and clastic material from the islands may in many cases even surpass the volume of the islands themselves. A major problem with appreciating the evolution of oceanic intraplate volcanism is the fact that most of the volume occurs under water. Our aim was to better understand the way ocean islands degrade by mass wasting triggered by internal and external causes and to determine the erosional history in terms of volumes and frequency of events for the entire Canary Ba$\sin$.

Ocean island volcanoes emerge above the sea when growth processes (magma intrusions and lava extrusions) exceed degradation by

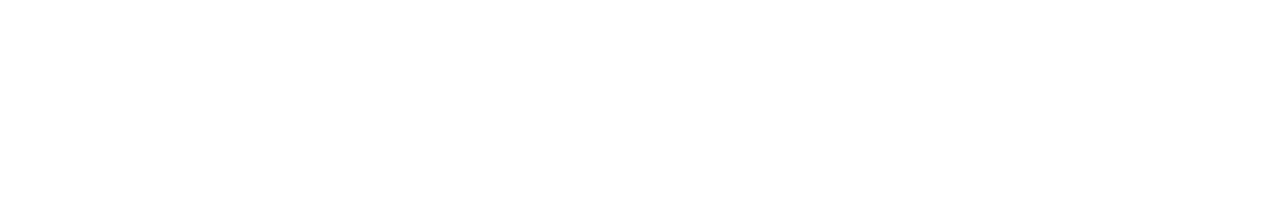


continuous and episodic mass wasting and subsidence. To better understand the way large oceanic intraplate volcanoes evolve, we drilled the clastic volcanic apron around Gran Canaria because of

1. Its 16-m.y. multiphase subaerial history, the pronounced compositional differences among mafic lavas erupted in temporally well-defined episodes, and their distinction from volcanic rocks from other Canary Islands;

2. Its frequent and voluminous explosive eruptions, chiefly as pyroclastic flows over 5 m.y., the abundance of K-bearing phenocrysts (anorthoclase and phlogopite) in evolved ignimbrites and lavas that allow precise single crystal dating over a period of $\sim 15$ m.y.; and

3. Its chemical, mineralogical, temporal, and volcanic evolution have been studied in detail (Schmincke, 1976, 1982, 1993; Hoernle and Schmincke, 1993a, 1993b).

We anticipated that the general lithostratigraphy at all four drill sites would closely resemble that of Gran Canaria, including major differences between the sites north and south of the island, because the geologic evolution of the northern half of Gran Canaria differs significantly from that in the south. By drilling into the volcanic apron, we expected to be able to more precisely date and characterize the submarine phases of volcanism of Gran Canaria and of the younger island of Tenerife, prerequisites for calculating progression of volcanism across the island chain and, therefore, plate kinematics or migration of the melting anomaly.

The plan for systematically analyzing the clastic apron of Gran Canaria by drilling grew from an analysis of basaltic volcaniclastic deposits drilled in Hole 397 (Deep Sea Drilling Project [DSDP] Leg 47A), $100 \mathrm{~km}$ southeast of Gran Canaria, that showed a systematic succession from deep water to emergent conditions with time (Schmincke and von Rad, 1979; Schmincke, 1982). Debris-flow deposits were thought to represent the intermediate, shallow-water, and shield stages of emerging Fuerteventura and Gran Canaria, judging from their textural characteristics and chemical and mineralogic composition. Major volumes of clastic debris were thought to be generated during the transition period seamount/island by phreatomagmatic and magmatic explosive activity, as well as erosion of freshly formed pyroclastic deposits.

This pattern has been basically confirmed by drilling during Leg 157. A more elaborate model can now be proposed, however, because of the much thicker sections drilled (altogether $\sim 3000 \mathrm{~m}$ ), coarser grain size of many deposits, and the closer proximity of all four holes to Gran Canaria compared with DSDP Site 397.

Although drilling during Leg 157 was not deep enough and not close enough to the island to intersect and recover rocks representing the very deep-water stage, we now have excellent material with which to document the intermediate- to shallow-water developmental stage in the growth of volcanic islands that is generally inaccessible for systematic scientific study. We also sought to identify volcaniclastic deposits that are not preserved and/or recognized on land, that are covered by younger formations, that have been eroded or formed below sea level, or that are transported during eruptions chiefly to the sea.

Other aims included calibration of the biostratigraphic and paleomagnetic record against single crystal ${ }^{40} \mathrm{Ar} /{ }^{39} \mathrm{Ar}$ age dates; calculation of sediment budgets for the submarine growth, subaerial evolution, and unroofing of Gran Canaria; chemical fluxes between volcanic glass and seawater; and response of the lithosphere to loading and heating during magmatic activity. We hoped to acquire sufficient data to allow a more realistic assessment of the past volcanic, petrologic, and plate tectonic environments of sedimentary basins adjacent to productive volcanic source areas, with the evolution of a prototype volcanic apron serving as a model for the interpretation of ancient marine sections on land as well as marine volcaniclastic successions drilled during DSDP and Ocean Drilling Program (ODP) legs.

\section{THE CANARY ISLANDS}

The Canarian Archipelago, one of the major volcanic island groups in the Atlantic Ocean basin, consists of seven major islands (Lanzarote and Fuerteventura to the east; Gran Canaria, Tenerife, and Gomera in the center; and Hierro and La Palma in the west) rising from the continental rise and slope off northwest Africa and forming a 450-km-long, east-west volcanic belt, underlain by several presently active melting areas, from $115 \mathrm{~km}$ west of the African coast westward and for 100-200 km north-south, between $27^{\circ} 38^{\prime}$ and $29^{\circ} 255^{\prime}$ latitude and $13^{\circ} 20^{\prime}$ and $18^{\circ} 9^{\prime}$ longitude (Figs. 1-3). Tenerife, dominated by the 3718-m-high Pico de Teide, is the third largest oceanic volcano on Earth, next to Mauna Kea and Mauna Loa.

The presence of Mesozoic tholeiitic ocean crust beneath the Canary Islands is well supported by the occurrence of mid-oceanridge basalt- (MORB) type gabbro and basalt xenoliths in Lanzarote, Gran Canaria, and La Palma (Schmincke, 1994), and seismic refraction data indicate the ocean crust to be $\sim 4 \mathrm{~km}$ thick (Ye et al., in press; Fig. 4). The approximate eastern boundary of the oceanic crust is defined by magnetic Anomaly S1 east of Fuerteventura and Lanzarote and agrees with the seaward extent of a series of salt diapirs (Roeser, 1982; Hinz et al., 1982). In their plate kinematic reconstruction, Klitgord and Schouten (1986) dated this anomaly as $\sim 175 \mathrm{Ma}$ and Anomaly M25 at the westernmost Canary Islands of La Palma and Hierro as $\sim 156 \mathrm{Ma}$. The lithosphere is $\sim 100 \mathrm{~km}$ thick beneath the western Canaries, thinning to $60 \mathrm{~km}$ beneath the central Canaries (Ranero et al., 1995; Fig. 4).

The abundance of seamounts north and south of the Canaries (Fig. 1) forming a belt parallel to the African coast, and the very elongate ridge encompassing the eastern Canaries and Concepcion Bank, are persuasive evidence that the eruption of magmas along this belt is re-

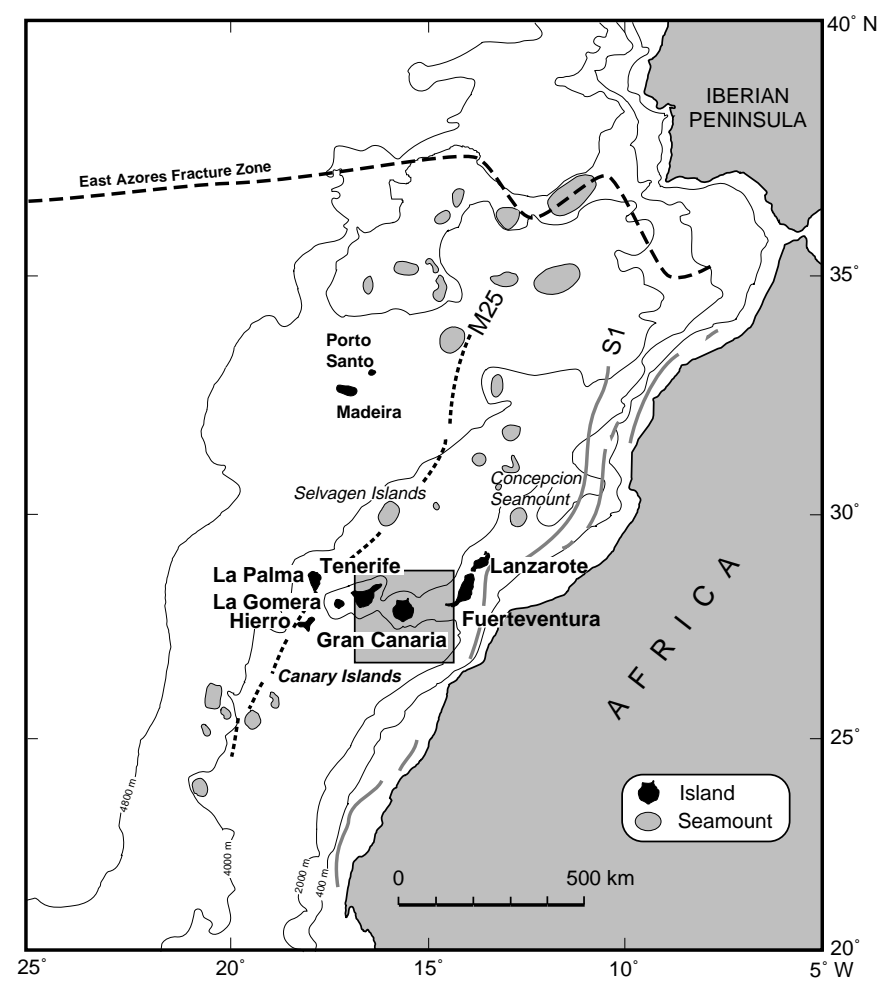

Figure 1. Location of island groups (Canary Islands and Madeira Islands) and major seamounts off the northwest African continental margin. The African plate is bounded to the north by the East Azores Fracture zone, between the Azores and Gibraltar. Seamounts north and south of the Canary Islands are shown with shaded patterns. Magnetic anomalies M25 after Klitgord and Schouten (1986), and S1 after Roeser (1982). 


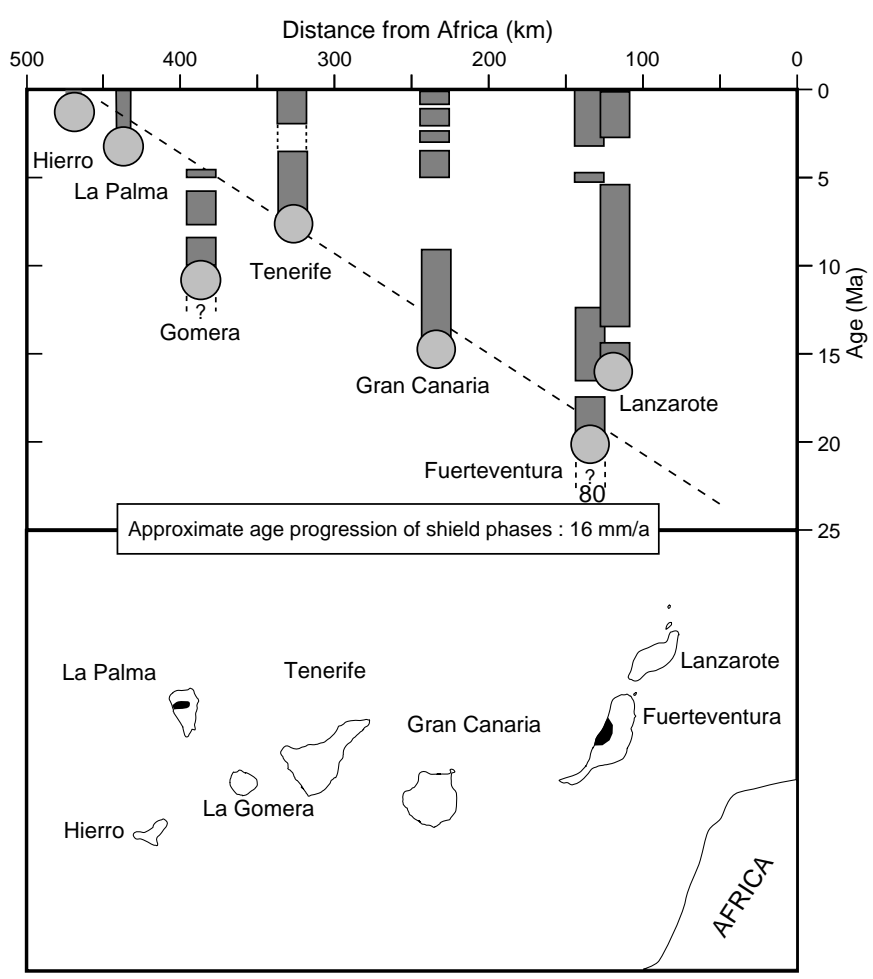

Figure 2. Map of the Canary Islands and age distribution of major volcanic phases shield stages shown by circles. Age data are mostly from AbdelMonem et al. (1971, 1972), McDougall and Schmincke (1977), Cantagrel et al. (1984), Feraud et al. (1981), Ancochea et al. (1990, 1994), Coello et al. (1992), Bogaard et al. (1988), and Bogaard and Schmincke (Chap. 11, this volume). Black areas on Fuerteventura and La Palma show large uplifted basal complexes.

lated to the suture zone between the continental and oceanic lithosphere (Schmincke, 1982). The much lower plate velocity of the African plate, the deeper origin of the western Canary Island magmas, and a major difference in plume dimensions and dynamics appear to be the main causes of these differences and may explain the more heterogeneous magmatic, temporal, structural, and volcanic evolution of the Canaries, compared with Hawaii. The magmas may have been generated by a weak, possibly intermittent, plume that may have spread westward beneath the lithosphere, reflecting westward propagation of the island group.

The igneous rocks of the Canary Islands encompass a broad spectrum of chemical compositions and mineralogy, ranging from hypersthene-normative tholeiitic basalts to highly undersaturated melilite nephelinites among the mafic lavas; low-silica rhyolites to hauyne phonolites; and layered ultramafic rocks and gabbros to alkali gabbros and syenites among the plutonic rocks. Compared with Hawaiian magmas, Canarian magmas are low in $\mathrm{Al}$ and higher in $\mathrm{Ti}$ and $\mathrm{Fe}$ at equivalent Mg-numbers, indicating derivation from a garnet-bearing source with garnet as a residual phase, also suggested by the sparse rare-earth element (REE) data (Schmincke, 1982). The increasing alkalis and Fe and Ti concentrations and the absence of tholeiitic lavas on Tenerife and the western islands suggest higher pressure of partial melting, as also reflected in the eastward thinning of the lithosphere (Fig. 4).

As new data have become available, the differences between the Hawaiian Islands (Moore and Fiske, 1969; Clague and Dalrymple, 1987 ) and the Canary Islands (see "Summary" in Schmincke, 1994) have become more apparent, but the basic similarities are still impressive. The shields of the Canaries are smaller in volume than those of the Hawaiian Islands. Recent seismic data from the volcanic apron of Gran Canaria have shown that a large part of the basal cone is hid- den by sediments, however, necessitating an upward estimate of the volume of Gran Canaria from the base of the seismically defined apron, but disregarding the seismically documented central core beneath as $\sim 30,000 \mathrm{~km}^{3}$ (Funck and Schmincke, in press; Fig. 5). The subaerial volume makes up only $2.5 \%$ of the total volume. About 0.2 $\mathrm{km}^{3} / \mathrm{ka}$ of volcanic material was deposited in the Madeira Abyssal Plain over the past 0.6 m.y. probably derived from the Canary Islands (Weaver, pers. comm., 1994). The volume of the volcanic components in the clastic apron of Gran Canaria-and, for that matter, of the other islands - plus the volume of volcaniclastic debris carried to the Madeira Abyssal Plain, and the amount deposited on the way as debris flows may be even larger.

Although most of the evolution of oceanic volcanoes takes place under water, very little about this development is known. The structure, composition, and evolution of the submarine part of the Canary Islands are poorly understood, except for La Palma, where a $2.5-\mathrm{km}$ thick section of the uplifted submarine part is well exposed (Schmincke and Staudigel, 1976; Staudigel and Schmincke, 1984). The hyaloclastite debris flows and turbidites from the upper part of the submarine section are overlain by volcaniclastic debris flows that contain abundant tachylite and a wide variety of subaerial volcanic and subvolcanic rock fragments.

The main stage in island growth is the construction of one or more large basaltic shield volcanoes, making up $90 \%$ or more by volume of an island, followed by erosional intervals lasting a few million years, and culminating in less voluminous and more alkalic magmatic phases and some differentiated lavas.

Volcanic activity following the initial shield stage lasts much longer on the Canary Islands than in Hawaii (Fig. 2). The evolution of the eastern islands differs significantly from that of the central edifices (Gran Canaria, Tenerife, and Gomera), whereas the young islands Hierro and La Palma are still in their shield stage. The basaltic shields of Fuerteventura and Lanzarote, located on the southern part of the $\sim 400-\mathrm{km}$-long East Canary Ridge, developed during up to 6, exceptionally 10 m.y. (Coello et al., 1992), with the construction of several shields along the length of the islands having occurred from $\sim 22$ to $<10 \mathrm{Ma}$ (northern Lanzarote). Subaerial activity on Fuerteventura has lasted intermittently for $\sim 20$ m.y. and for $\sim 16$ m.y. on Lanzarote and Gran Canaria. Excluding La Gomera, Holocene and historic to prehistoric eruptions occurred on all islands, with the one on Lanzarote (1730-1736) being the second largest basaltic eruption on Earth in historic times.

The number of post-erosional or rejuvenated alkalic stages in the Canary Islands (Fig. 2) is higher than that in the Hawaiian Islands, as is the relative volume. In other words, unlike in the Hawaiian chain where islands are shut off from the magma supply after $\sim 5$ m.y. (i.e., after the rejuvenated phase), melting anomalies under the Canary Islands release magmas for tens of millions of years once they have become productive beneath an island. The large volume of evolved rhyolitic, trachytic, and phonolitic magmas on several islands is unusual among oceanic islands and must require optimal magma replenishment rates large enough to thermally and materially keep the system alive, but small enough to allow extreme fractionation to occur.

\section{Evolution of Gran Canaria and Drilling Goals}

Gran Canaria $\left(28^{\circ} 00^{\prime} \mathrm{N}, 15^{\circ} 35^{\prime} \mathrm{W}\right)$ is the central island of the Canarian Archipelago, $200 \mathrm{~km}$ off the northwest African passive continental margin. Three major magmatic/volcanic phases have been further subdivided into several stages (Schmincke, 1976, 1982, 1994; Hoernle and Schmincke, 1993a, 1993b; Figs. 3, 6, 7). A condensed stratigraphic description is given by Sumita and Schmincke (Chap. 15, this volume), and a summary of age determinations made on rocks from Gran Canaria is presented by Bogaard and Schmincke (Chap. 11, this volume).

The composition and age of the submarine part of the island are unknown. All subaerially exposed volcanic and intrusive rocks were 


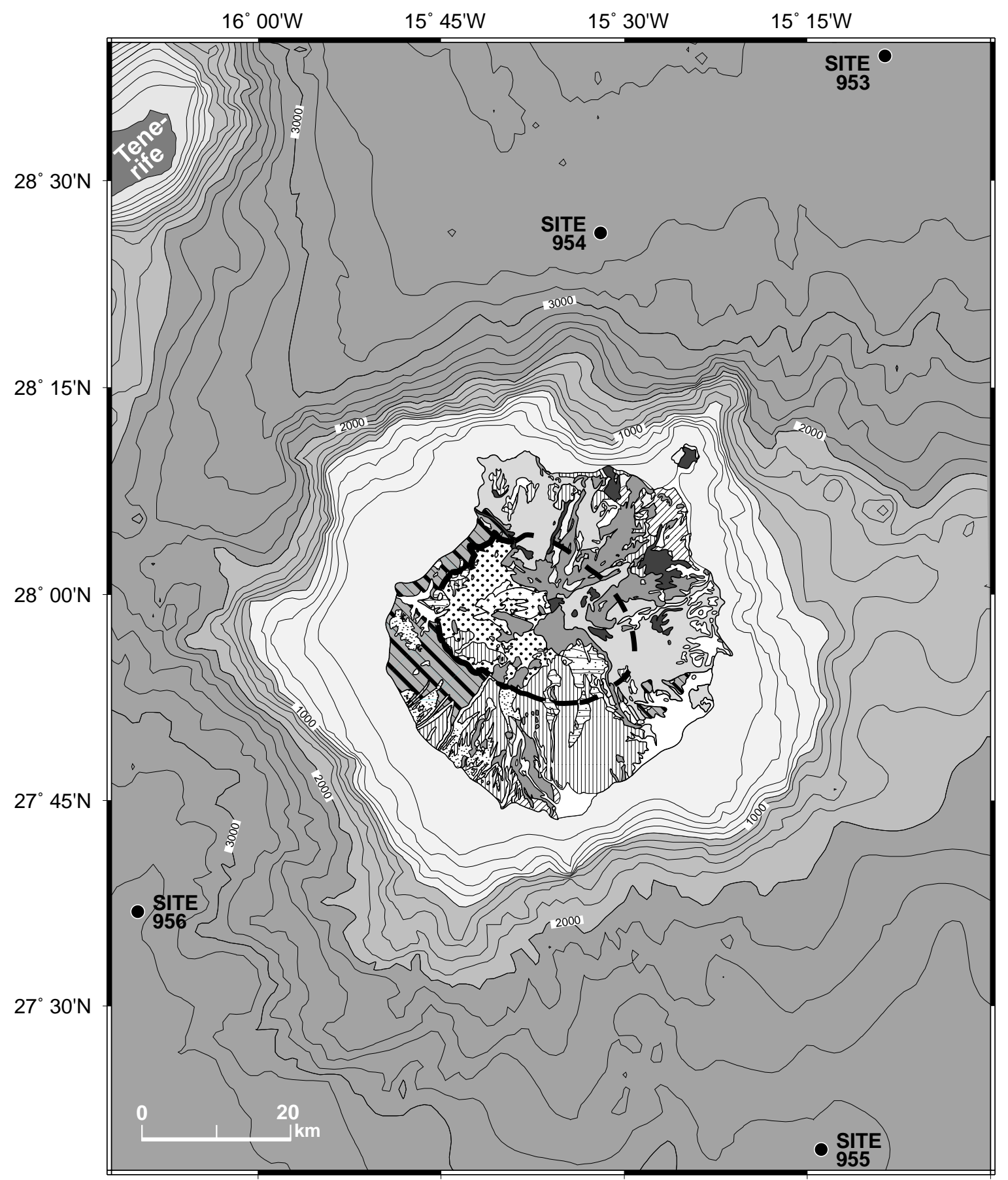

\begin{tabular}{|lll|}
\hline Pleistocene - Holocene & Roque Nublo Group & $\ddots$ L Intracaldera volcanics \\
Hond dikes \\
Holocene basalts & Las Palmas Fan & Mogán Group \\
Pliocene/Pleistocene basalts & Fataga Group & Caldera rim \\
\hline Landslide areas & Shield basalts \\
\hline
\end{tabular}

Figure 3. Simplified geologic map of Gran Canaria and Leg 157 sites. Bathymetry between 0 and 1000, 2000, and 3000 mbsl is shown in increasing shades of gray. After various sources from Schmincke (1994). 


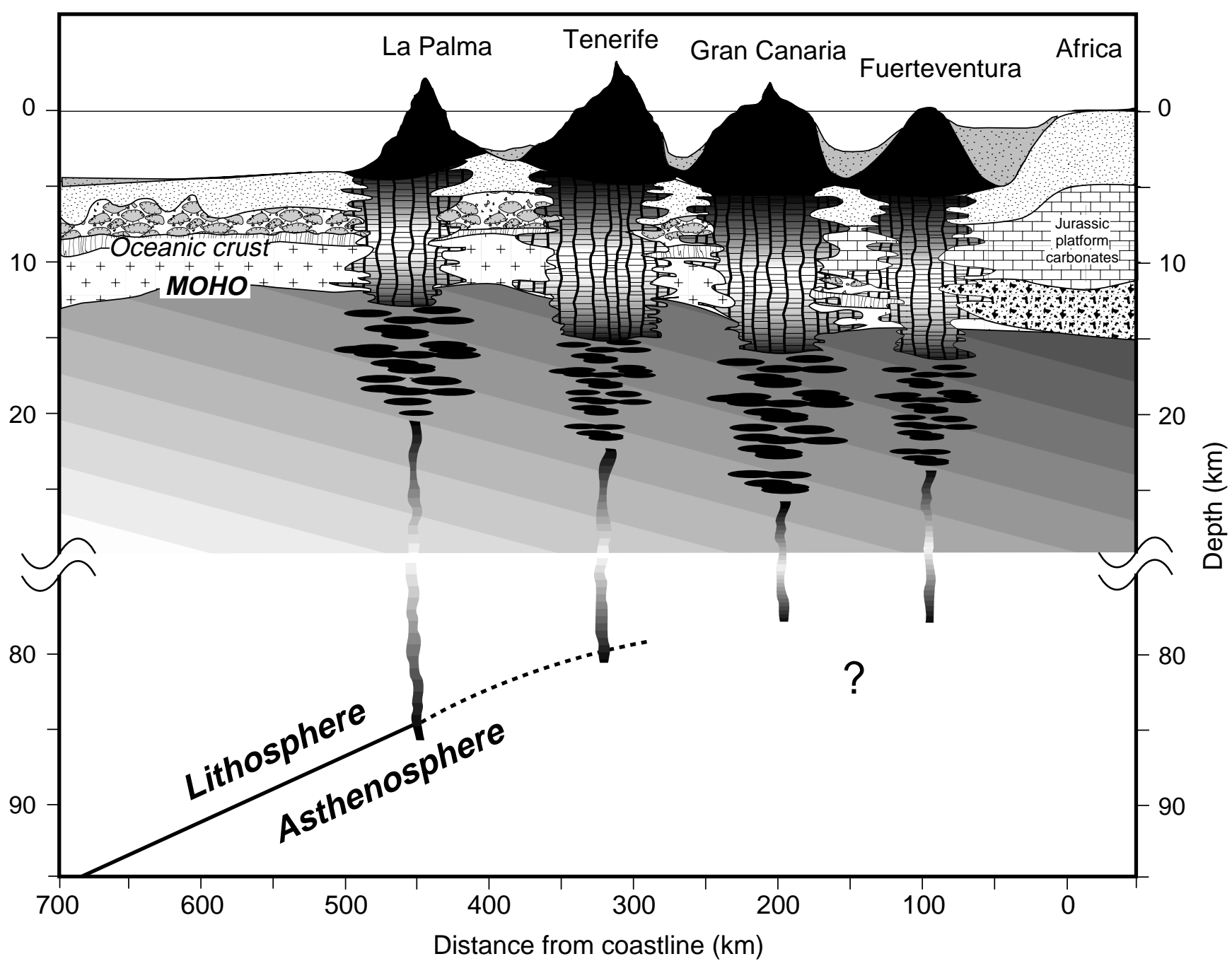

Figure 4. Crustal and mantle structure beneath the Canary Islands and the African continental margin, based on Bosshard and MacFarlane (1970), Banda et al. (1981), Ranero et al. (1995), and Ye et al. (in press). Jurassic platform carbonates and pre-Jurassic rocks extend westward from the continental margin probably to Gran Canaria. They are overlain by Cretaceous and Tertiary sediments, the Neogene section (darker gray) being dominated by volcaniclastic sediments of the volcanic aprons. The ocean crust in which the sheeted dike section may be very thin extends eastward to beneath the eastern Canaries. The thickness of the lithosphere beneath Gran Canaria and the eastern Canaries is uncertain.

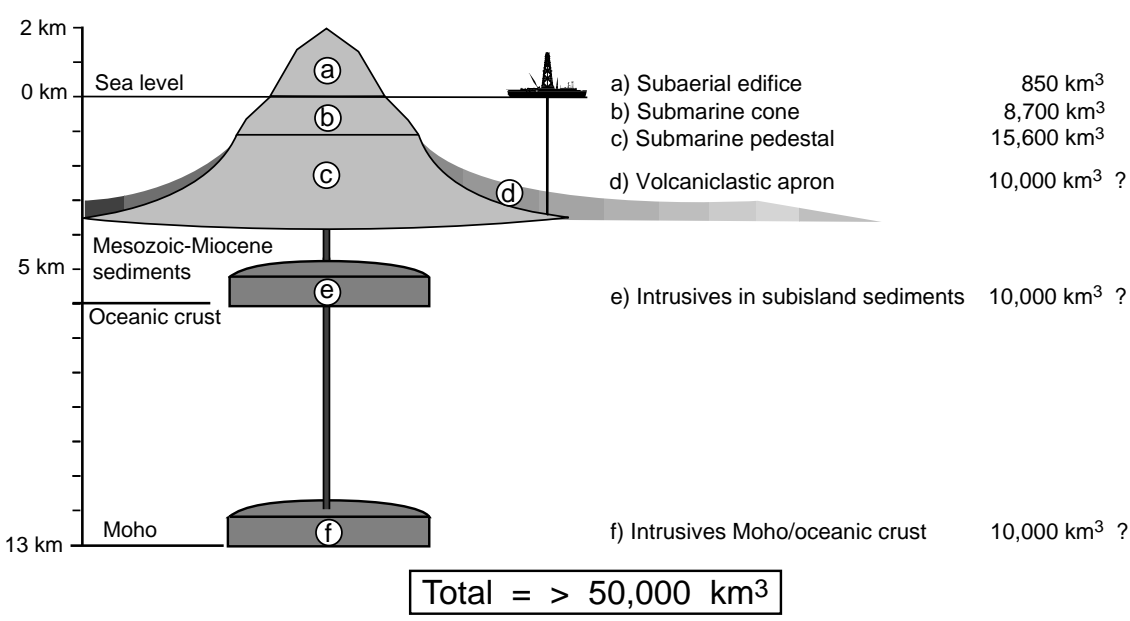

Figure 5. Volume estimates of volcanic island system. Volumes a through $\mathrm{d}$ are reasonably well supported for Gran Canaria by bathymetric and seismic data, whereas partial volumes d, e, and f are highly speculative. Modified from Schmincke (1994) and Funck and Schmincke (in press). 


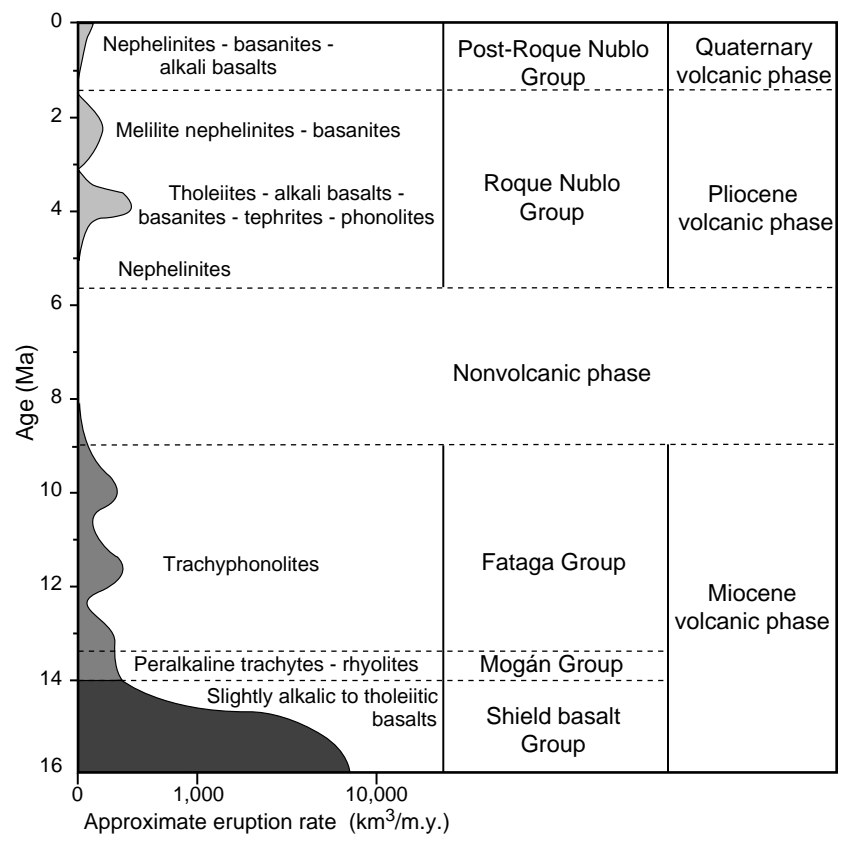

Figure 6. Lithostratigraphy of Gran Canaria showing eruptive rates of major volcanic phases. Modified from Schmincke $(1976,1994)$ and Hoernle and Schmincke (1993a).

emplaced within the past 16 m.y. The subaerial Miocene phase started with the rapid formation of the exposed tholeiitic to mildly alkalic shield basalts whose erosional remnants rise to $\sim 1000 \mathrm{~m}$ above sea level (masl). A major goal of the drilling project was therefore to record at least part of the submarine evolution of Gran Canaria with the aim to date the deposits and to determine their mineral and chemical compositions, water depth of eruption, and source area. In view of the 60- to 80-m.y.-long history of Fuerteventura, whose Miocene shield lavas are underlain by the Mesozoic to middle Tertiary basal complex, Le Bas et al. (1986) suggested that other Canary Islands might have a similar structure and history beneath their "similarly strongly alkaline island-capping lavas." We consider the shield lavas of the eastern and central islands to be mildly alkalic to tholeiitic, but the possible existence of major uplifted plutonic complexes and major dike swarms beneath Gran Canaria could not be excluded a priori, and drilling was one method to distinguish between the scenario of Le Bas et al. (1986) and that of Staudigel and Schmincke (1984).

Geologic evidence suggests a decrease in age of subaerial shield volcanism on Gran Canaria from east to west because the ignimbrite sheet P1, which heralded 5 m.y. of evolved explosive volcanism and covered most of the island, is practically conformable in the west while overlying deeply eroded shield lavas in the east, an area which locally was covered by fanglomerate slope debris deposits before ash-flow eruptions (Schmincke, 1976). Moreover, the evolved aphyric to strongly plagioclase-phyric lavas of the Horgazales Formation in the west below ignimbrite P1 have not yet been found in the east. Drilling north and south of the island was expected to provide essential clues to the migration of shield basalt volcanism on Gran Canaria.

The shield basalts are covered by more than $200 \mathrm{~m}$ of peralkaline trachytic to rhyolitic ignimbrites and minor lavas $(\sim 15$ chemically and mineralogically distinct cooling units of the Mogán Group, 1413.4 Ma; between 300 and $500 \mathrm{~km}^{3}$ dense rock equivalent (DRE) of dominantly peralkaline trachytic, comenditic and pantelleritic magmas [Schmincke, 1994]), overlain locally by more than $500 \mathrm{~m}$ (probably $>500 \mathrm{~km}^{3}$ ) of trachyphonolitic ignimbrites and lava flows (Fataga Group, 13.4-8.5 Ma) erupted from a large ( $20 \mathrm{~km}$ in diameter) caldera. In total, more than $1000 \mathrm{~km}^{3}$ of felsic magma was erupted on land over a period of more than 5 m.y. The ash flows erupted at intervals of 0.04-0.05 m.y. (Bogaard and Schmincke, Chap. 11, this volume). Almost no basalts were erupted subaerially during this time, except for a thin but widespread basalt unit (T4), which separates the middle and the upper Mogán Formations at 13.6 Ma. Minor fallout tuffs are preserved beneath some of the ignimbrite cooling units. Phonolite lava flows and fallout tephra are more common in the Fataga Group. Basanite and nephelinite dikes are very rare. Syenites and a large cone sheet swarm make up the central caldera complex from which Mogán and later Fataga volcanics were erupted.

We hoped to identify many of the Miocene ignimbrites and fallout ashes in their counterpart volcaniclastic turbidites, thereby enabling us to better calculate volumes of magmatic events, to quantify a unique scenario of land-sea correlations, and to help calibrate the biomagnetostratigraphic time scale. We also expected to distinguish primary from reworked volcaniclastic deposits and, thus, to be able to quantify erosional and volcanic phases and to understand the processes that occur when hot ash flows enter the sea.

Volcanic activity was practically absent on Gran Canaria between $\sim 9$ and 5 m.y. ago, and activity was low between $\sim 10$ and $9 \mathrm{Ma}$ and between 5 and 4 Ma (Schmincke, 1976; Bogaard and Schmincke, Chap. 11, this volume). During this time, the island, which may have stood more than $2000 \mathrm{~m}$ high, became strongly eroded, resulting in conglomerates and unconsolidated sands a few tens of meters thick between the deeply worn-down extrusive and intrusive rocks of the island and overlying lowermost Pliocene lavas. Widespread conglomerate and debris-flow fans had developed around Arguineguín in the south and on the lower Las Palmas Terrace in northeastern Gran Canaria. One goal of the drilling project was to compare and contrast the mass and nature of volcanic particles removed from the island during this 3- to 5-m.y.-long nonvolcanic interval with those of the older and younger periods, when volcanic activity was high.

The Pliocene phase began with minor nephelinites and basanites at $~ 5$ Ma. Subsequent Pliocene Roque Nublo volcanism formed a stratocone, possibly as high as $3000 \mathrm{~m}$, approaching present-day Pico de Teide on Tenerife in height. Alkali basaltic, tholeiitic, trachytic, basanitic, and phonolitic lavas, intercalated with characteristic massive, landmark hauyne-phonolite breccia flows, fallout ashes, and pumice flows, intruded by trachytic and hauyne phonolite domes (Roque Nublo Group) were emplaced mostly between 4 and $~ 3.5 \mathrm{Ma}$.

The southern and northern sectors of this central stratocone collapsed at $\sim 3.5 \mathrm{Ma}$. The southward-moving debris-avalanche deposits were channelized by steep paleovalleys, especially by Barranco de Arguineguín. That the debris-avalanche deposits are found at the present coastline in the south, northeast, and northwest suggests that the debris flows entered the sea. A broad mound in a major sediment fan that formed south-southeast off large canyons (Mogán, Arguineguín, and Fataga) is interpreted to represent deposits of the Roque Nublo debris avalanches (Funck and Schmincke, in press). Onshore, Mehl (1993) has mapped a $14 \mathrm{~km}^{3}$ of Roque Nublo debris avalanche. The most widespread among the many excellent seismic reflectors in the apron, R3, is interpreted as the submarine equivalent of the Roque Nublo debris avalanche (Funck et al., 1996; Krastel, 1995).

Following a possible brief gap in volcanism, mafic volcanics, comprising nephelinites, melilite nephelinites, and basanites, represent an unusually large volume of highly undersaturated mafic lava flows for oceanic islands. Quaternary volcanism, restricted to the northern half of the island, includes nephelinites, minor hauyne tephrites, and younger basanites. The island can be considered volcanically active, as testified by numerous late Holocene basanite scoria cones, maars, and lava flows, dated as $\sim 3,000$ years BP. The unsolved questions before drilling concerned the type and amount of volcanic debris transported into the northern basin during the voluminous, but largely effusive, late Pliocene and Pleistocene mafic volcanism on Gran Canaria, the possible addition by submarine volcanism off the 


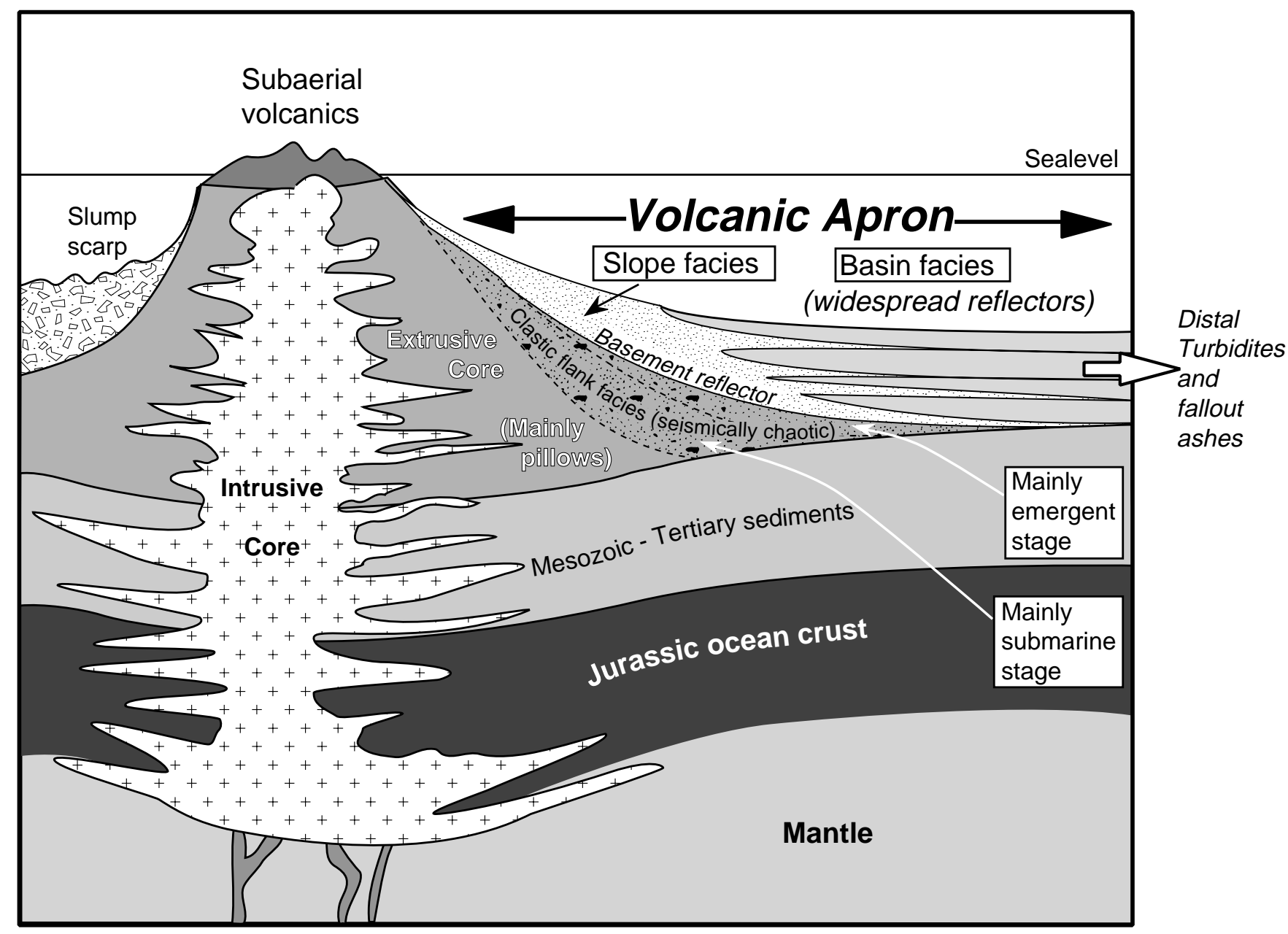

Figure 7. Schematic drawing of an ocean island and its clastic volcanic apron. The intrusive and extrusive core facies is overlain by the seismically "opaque" flank facies consisting of basaltic volcaniclastic rocks of the submarine and emergent stage. The sediments of the volcanic apron above the basement reflector are subdivided into a slope facies characterized by slumps and the basin facies with more continuous reflectors. Modified from Schmincke (1994).

northern flank of the island, and the likely absence of Pliocene-Pleistocene volcaniclastic sediments in the southern sites-except for expected influx from Tenerife in the southwest.

Landslides and debris avalanches have contributed to the destruction of Gran Canaria dominantly at the end of the basaltic shield phase, the late Fataga phase, and the end of the Roque Nublo phase. For example, the submarine flanks and coastlines of Gran Canaria show major, wide reentrants interpreted as sector collapses (e.g., in the northwest coast [Funck and Schmincke, in press]), similar to those recognized by Moore et al. (1994) in the Hawaiian Islands. We speculate that flank collapses triggered one or more major slumps and debris flows whose dispersal path was aimed at the Madeira Abyssal Plain, whose deposits appeared as strong seismic reflectors around Gran Canaria, and which we expected to intersect in one or more of the drill holes (Funck et al., 1996).

Three major changes in climate during the evolution of Gran Canaria have been recognized based primarily on information gained from marine sediments and secondarily on land evidence. The most important land evidence shows a striking subdivision between high degrees of erosion in the north and east and a dry shadow zone in the south, which has remained remarkably constant since the basaltic shield building activity $\sim 15-16$ m.y. ago. Superimposed on this pattern are changes from a dry climate with minor dissection during the Mogán interval to increasing wetter climate, leading to canyon cut- ting and generation of conglomerates during the Fataga interval, after $\sim 12$ m.y. ago.

The late Miocene climate of northwest Africa, as deduced from marine evidence, alternated between prolonged arid and shorter humid periods (Diester-Haass, 1979). It is unknown whether the deep and major dissections of the island between $\sim 9$ and 4 Ma were climate controlled or were dominantly the result of the absence of constructive volcanic activity. Abundant traces of vegetation at high altitudes (Schmincke, 1967) and very abundant conglomerates (Schmincke, 1976) are strong evidence that wet and warm conditions prevailed during Roque Nublo volcanic activity between $\sim 4$ and 3.5 $\mathrm{Ma}$. The Pleistocene is characterized by numerous periods of humid and arid climate changes and corresponding sea-level fluctuation. During humid (glacial) periods, fluvial systems and soils developed, whereas eolian processes dominated during arid (interglacial) times. We hoped to find evidence in the drill cores of both major climate and sea-level changes on the islands and in nearby Africa.

The recognition of global sea-level changes on oceanic islands is highly compromised by the possibility of major isostatic sinking during island growth periods, as in Hawaii (Moore, 1970a). However, Gran Canaria appears to have been extremely stable since at least the late shield-building stage, as shown by land evidence (Schmincke, 1968) and the nearly horizontal attitude of major reflectors north of the island (Funck and Schmincke, in press). Hence, we expected the 
sediment response to glacially controlled sea-level changes to be reflected in the cores. Sea-level changes have been called upon in the past by several workers to explain clastic sedimentation on and off Gran Canaria, particularly major conglomerate and piedmont fans in the south (Arguineguín Fan), northeast (Las Palmas Fan), and southeast (lower Barranco de Tirajana Fan). Lietz (1973) showed that the accumulation of very thick gravel fans occurred mainly during falling, not rising, sea level. The southern and northeastern phonolitic fans formed between $\sim 8$ and $10 \mathrm{Ma}$, a marine transgression, documented as high as 150 meters above sea level (masl), occurred at $\sim 4$ $\mathrm{Ma}$, and a subsequent regression leading to deposition of widespread basaltic gravels (the younger Tirajana Fans) may owe its origin to glacially triggered sea- level drops during the early Pleistocene.

\section{VOLCANIC APRON}

The term "archipelagic apron" was introduced by Menard (1956) for the seismically recognized peripheral apron around volcanic islands, and he believed the apron consisted of lavas and sediments. It has been used in recent years by geophysicists in a more restricted sense for the higher velocity bulk of the submarine cone of an oceanic island that is seismically "opaque" or "chaotic" and that is characterized by discontinuous reflectors and rough topography (e.g., Wissmann, 1979; Holik et al., 1991). The volcanic apron, as used here, also includes the volcaniclastic sediments in the basins adjacent to the volcanic edifice, which may extend for more than $100 \mathrm{~km}$ around an island. The volcanic debris in volcanic aprons may equal or exceed the volume of the volcanic island.

A volcanic apron peripheral to an oceanic island can be subdivided into several facies (Schmincke, 1993; Fig. 7). The submarine cone is thought to consist largely of intrusives and pillow lavas, densely packed and nonvesicular at depth, that become increasingly vesicular and interlayered with pillow breccias and pillow fragment breccias, debris flows and intrusions, and primary and resedimented hyaloclastites upward. The outer limits of the seismically defined flanks are clearly identifiable in the profiles down the slopes of Gran Canaria, Tenerife, and Fuerteventura (Funck et al., 1996).

We can subdivide this part of the cone into a core and overlying seismically opaque flank facies that have not been distinguished from each other seismically but can be separated from each other in the field, as on La Palma (Staudigel and Schmincke, 1984). The core facies of intrusive and extrusive rocks were not drilled during Leg 157. The flank facies, which contain only minor nonvolcanic sediments, can be subdivided lithologically into the main hyaloclastite facies, represented by hyaloclastic lapillistones and breccias of which the upper part was drilled in Sites 953, 954, and 956, and the outer volcaniclastic veneer, which consists of basaltic turbiditites and debrisflow deposits as much as hundreds of meters thick and which represents the emergent stage. The flank facies may extend laterally beneath the slope and basin facies.

The sediments above the flank facies are subdivided into two main facies. The proximal or slope facies, characterized by slumps, discontinuous bedded units, debris flows, and erosional channels extends to $\sim 50 \mathrm{~km}$ off Gran Canaria. Site 954 was drilled into the outer slope facies.

The slope facies grades laterally into the basin facies, characterized by more continuous, well-developed single or grouped reflectors. It consists of diverse types of volcaniclastic deposits including fallout ash layers, debris flows, distal ignimbrites, and other volcaniclastic rocks generated by eruptions, erosion, and flank collapse of the volcanoes. The volcaniclastic deposits are interbedded with background biogenic and/or siliciclastic terrigeneous sediments. Volcanic debris flows from the Canaries, and distal volcanic turbidites can be traced to the area of the Madeira Abyssal Plain $1000 \mathrm{~km}$ to the west (Masson, 1996).

\section{Seismic Stratigraphy of the Apron Around Gran Canaria}

Submarine volcaniclastic sequences contain strong seismic reflectors, but the nature of single reflectors or groups of reflectors varies widely. In fact, the plan for drilling the clastic apron of Gran Canaria arose from the drilling of major reflectors during Leg 47A, originally thought to represent Eocene cherts or the Tertiary/Cretaceous boundary, but which turned out to be middle Miocene volcaniclastic debris-flow deposits (Wissmann, 1979). One of the major objectives of the cruise, therefore, was to intersect at least the major reflectors and to compare the predicted depth, stratigraphic correlation, rock type, and mode of origin. Especially widespread seismic reflectors in marine sediments around the Canary Islands are interpreted as volcaniclastic debris-flow sheets (Wissmann, 1979; Schmincke and von Rad, 1979).

The sediments overlying the submarine island flanks (acoustic basement) of Gran Canaria, Tenerife, and Fuerteventura were studied by high-resolution reflection seismics during the main presite survey for the Volcanic Island Clastic Apron Project (VICAP), part of Leg 157 (Schmincke and Rihm, 1994; Funck et al., 1996; Krastel, 1995). In the Canary Basin north of Gran Canaria, the apron flank is well defined by reflection and refraction data. The top of the flank facies was recognized to be as deep as 900 meters below seafloor (mbsf). Sediments with seismic $P$-wave velocities from 3.4 to $4.6 \mathrm{~km} / \mathrm{s}$ extend out to a distance of $40-60 \mathrm{~km}$ off the coast and are underlain by $\sim 2.5-3$ $\mathrm{km}$ of prevolcanic sediment layers characterized by lower velocities of $3.0-3.2 \mathrm{~km} / \mathrm{s}$ (Ye et al., in press; Fig. 3).

The edge of the flank of Gran Canaria extends $30-60 \mathrm{~km}$ away from the shoreline. The flank of Tenerife onlaps the steeper and older flank of Gran Canaria in the channel between the two islands. The Meteor M24 profiles were connected to DSDP Site 397 (von Rad, Ryan et al., 1979), and the seismic reflectors R3 (Pliocene Roque Nublo formation) and R7 (Miocene volcaniclastic debris flows) were correlated from Site 397 to the proximal southern apron of Gran Canaria.

The 15- to 16-m.y.-old shield of Gran Canaria was ponded against Fuerteventura to the east, forming a topographic barrier between the islands. To the north, the flank of Gran Canaria extends $\sim 60 \mathrm{~km}$ seaward to a depth of $\sim 4500 \mathrm{~m}$. The shield of the Anaga massif on northeast Tenerife onlaps the flank of Gran Canaria to the east. The feather edge of the Anaga shield ( $\sim 50 \mathrm{~km}$ off Tenerife at a depth of 4000 meters below sea level [mbsl]) has been correlated seismically to $\sim 6-$ m.y.-old sediments at Site 953.

The correlation of numerous closely spaced reflectors acquired during the presite survey with the lithostratigraphy at Site 953 was achieved by computing a synthetic seismogram serving as a link between seismic and borehole data (Funck and Lykke-Andersen, Chap. 2 , this volume). On board, velocity and density measurements were used in unlogged intervals to obtain a complete synthetic seismogram. Most reflectors in the upper $\sim 900 \mathrm{~m}$ above the flank facies (lithologic Units I-V at Site 953) are thin volcaniclastic layers intercalated with hemipelagic biogenic sediments.

\section{Response of the Lithosphere to Loading}

The bathymetry around oceanic intraplate volcanic complexes is determined by the density-, thickness-, and age-dependent static equilibrium of underlying oceanic basement; subsidence by loading with the volcanic edifices and their volcaniclastic aprons (Watts and ten Brink, 1989); subsidence by loading with continent-derived sediments; and uplift by reheating of the lithosphere caused by thermal anomalies in the mantle associated with intraplate volcanism, or by dynamic uplift. Heat-flow values estimated for Sites $954(54 \mathrm{~mW} /$ $\left.\mathrm{m}^{2}\right), 955\left(44 \mathrm{~mW} / \mathrm{m}^{2}\right)$, and $956\left(36 \mathrm{~mW} / \mathrm{m}^{2}\right.$; Floyd and Hood, unpubl. data) are lower than values expected for the surrounding crust $(50$ $\mathrm{mW} / \mathrm{m}^{2}$; Parsons and Sclater, 1977), assuming an age of 150 Ma. 
These low values may favor a dynamic uplift model for the Canary Islands' hot spot area, rather than reheating of the lithosphere. Floyd and Hood (unpubl. data) also discuss other factors to explain the unexpectedly low heat-flow values. These include a high degree of slumping at these sites and high sedimentation rates. Additionally, the higher thermal conductivities of suspected submarine shield basalts may contribute to a reduction in the vertical component of heat flux, estimated from measurements in the sediments on board.

Layers of volcaniclastic sediments that could be traced by multichannel seismic methods to $>200 \mathrm{~km}$ from the Hawaiian Island of Oahu dip toward the island in its immediate surroundings, rather than away from it (Watts and ten Brink, 1989). This inclination indicated to Watts and ten Brink the degree of loading of the islands. The volcaniclastic sediments shed from the Hawaiian Islands are ponded largely in the depot center formed by the moat that developed next to the islands as a result of this loading (Rees et al., 1993).

In the case of the Canary Islands, the relative scale of these effects is a matter of ongoing debate. Funck and Schmincke (in press) provide abundant evidence that Gran Canaria was fairly stable for the past $\sim 14$ m.y., despite an alternation of major volcanic and erosional phases. This is clearly shown by the fairly flat reflectors of the basin facies north and northeast of the island, except for a subtle dip of a reflector assigned to the basaltic shield phase toward the island, indicating a subsidence of at most $1000 \mathrm{~m}$ (Funck et al., 1996). The slope break at a depth of $600 \mathrm{~m}$ might be interpreted as the transition between subaerial and subaqueous chilled lavas at the end of the shield building (i.e., the present depth gives the amount of subsidence caused by the volcanic load on the lithosphere). The sinking practically terminated with the waning phase of basaltic shield volcanism (Funck et al., 1996; Funck and Lykke-Andersen, Chap. 2, this volume). The flat reflectors north of Gran Canaria that extend to northern Tenerife contradict the $2500 \mathrm{~m}$ postulated for Tenerife by Watts and Masson (1995).

\section{VOLCANICLASTIC DEPOSITS Site 953}

Site 953, located $60 \mathrm{~km}$ northeast of Gran Canaria, was drilled at a water depth of $3578 \mathrm{~m}$. Drilling penetrated a total of $1159 \mathrm{~m}$ of sediments, with a recovery rate of $103 \%$ (Hole 953A, $193 \mathrm{~m}$ cored) and 57\% (Hole 953C, $972 \mathrm{~m}$ cored).

The bulk of the volcaniclastic sediments occurs in Units IV-VII. Unit IV (398-850 mbsf) contains numerous interbedded rhyolitictrachypohonolitic volcaniclastic sediments correlated with the Miocene Fataga and Mogán Groups as follows:

Unit V (850-889 mbsf), consists of nannofossil mixed sedimentary rock, nannofossil claystone, claystone, lithic crystal siltstones and sandstones, and lapillistone.

Unit VI (889-969 mbsf) consists largely of thick to very thick bedded basaltic sandstone, lapillistone, and breccia with minor interbedded calcareous claystone and nannofossil-mixed sedimentary rock.

Unit VII (969-1158.7 mbsf) consists entirely of dark green hyaloclastite tuffs, lapillistones, and breccias.

\section{Site 954}

Site 954, located $45 \mathrm{~km}$ northeast of Gran Canaria, $100 \mathrm{~km}$ west of Fuerteventura and $100 \mathrm{~km}$ east of Tenerife, was drilled at a water depth of $3485 \mathrm{mbsl}$. Drilling penetrated a total of $446 \mathrm{~m}$ of sediments, with a recovery rate of $96 \%$ (Hole 954A, $84 \mathrm{~m}$ cored) and $45 \%$ (Hole 954B, $366 \mathrm{~m}$ cored).

The bulk of the volcaniclastic sediments occurs in Unit IV. Unit IV (408-446 mbsf) comprises exclusively dark green to gray struc- tureless, very poorly sorted, basaltic breccia. A large hiatus occurs between Units III and IV.

\section{Site 955}

Site 955, located in the southern Canary Channel on the southeastern volcanic apron of Gran Canaria, $55 \mathrm{~km}$ southeast of Gran Canaria and $110 \mathrm{~km}$ southwest of Fuerteventura, was drilled at a water depth of $3485 \mathrm{mbsl}$. Drilling penetrated a total of $599 \mathrm{~m}$ of sediments, with a recovery rate of $89 \%$. lows:

The bulk of the volcaniclastic sediments occurs in Unit IV as fol-

Unit IV (374-567 mbsf) contains numerous interbedded rhyolitic-trachypohonolitic volcaniclastic sediments correlated with the Miocene Fataga and Mogán Groups. Zeolitized tuffs are common in Subunit IVA (Fataga), whereas abundant fresh glass occurs in Subunit IVB (Mogán).

Unit V (567-599 mbsf) marks a return to hemipelagic sedimentation with thin interbedded siliciclastic sediments and minor basaltic sands and silts.

\section{Site 956}

Site 956, located in the southern Canary Channel, $60 \mathrm{~km}$ southwest of Gran Canaria and $65 \mathrm{~km}$ southeast of Tenerife, was drilled at a water depth of $3453 \mathrm{mbsl}$. Drilling penetrated a total of $704 \mathrm{~m}$ of sediments, with a recovery rate of $99.3 \%$ (Hole 956A, $160 \mathrm{~m}$ cored) and $54.4 \%$ (Hole 956B, $546 \mathrm{~m}$ cored).

The bulk of the volcaniclastic sediments occurs in Units IV and V as follows:

Unit IV (370-564 mbsf) contains numerous interbedded rhyolitic-trachypohonolitic volcaniclastic sediments correlated with the Miocene Fataga and Mogán Groups.

Unit V (564-704 mbsf) consists mostly of hyaloclastite tuff and lapillistone and basaltic breccia with minor interbeds of nannofossil claystone with foraminifers.

The high-resolution seismic stratigraphy established during the presite survey and carried out under way, and the synthetic seismograms correspond to lithologic subdivisions of the core and the impedance contrasts. The main basement reflector in the apron correlates at three sites (Sites 953, 954, and 956) with the top of the basaltic debris-flow deposits and breccias of the shield stage (i.e., the flank of the submarine shield volcano before burial by later sediments), but with the top of the younger volcaniclastic sediments correlated to the Mogán Group at Site 955. Abundant and continuous seismic reflectors outside the apron flanks around Gran Canaria represent distinct volcaniclastic layers or intervals of volcaniclastic sediments in the northern drill sites, but with major hiatuses identified in the accumulation curves in the southern drill Sites 955 and 956.

\section{The Submarine Basaltic Sequence}

Almost $500 \mathrm{~m}$ of basaltic volcaniclastic rocks, mostly hyaloclastite debris-flow deposits, turbidites, and breccias, were drilled in total at Sites $953(309 \mathrm{~m}), 954(38 \mathrm{~m}), 955(<2 \mathrm{~m})$, and $956(140 \mathrm{~m})$. Below, we use the expression "hyaloclastite intervals" to identify the basaltic volcaniclastic deposits interpreted to represent the shield stage of Gran Canaria and, possibly, adjacent islands, based on the dominant lithology. The upper stratigraphic boundary of these hyaloclastite intervals is precisely defined by a volcaniclastic unit representing the widespread ignimbrite P1 on top of the basaltic shield of Gran Canaria (Freundt and Schmincke, 1992, 1995a, 1995b; Chap. 14 , this volume). It is referred to here as P1 syn-ignimbrite turbidite 
and has an age of $13.9 \pm 0.3 \mathrm{Ma}$ (Bogaard and Schmincke, Chap. 11, this volume; Fig. 8).

At Site 953, the basal lithologic Unit VII consists of at least 190 $\mathrm{m}$ of massive hyaloclastite tuffs and lapillistones, forming an uninterrupted sequence of 16 debris flows. Most of the graded green hyaloclastite tuffs and lapillistones consist of weakly vesiculated shards and contain as much as 2 vol\% tachylitic and crystalline basaltic fragments, including oxidized scoria. Variably rounded and vesicular basalt clasts are strongly concentrated in the lower $\sim 10 \%-20 \%$ of a graded debris-flow deposit. Most basalt clasts have quench textures and probably represent true submarine basalts, or basalt flows, that entered the sea, but some may represent beach pebbles. The top 5\%$10 \%$ of graded units are fine grained and bedded. More vesicular shards (as much as $50 \%$ vesicles) occur in the top $20 \mathrm{~m}$ of the sequence.

Poorly recovered coarser grained deposits at Site 953 (lithologic Unit VI) range widely from hyaloclastite tuffs and lapillistones to lithic breccia containing altered sideromelane shards and basaltic fragments. Nannofossil-mixed sedimentary rocks with intercalated hyaloclastites separate the unit into lower more homogeneous basaltic lapillistones and upper, coarser grained breccias.

The upper submarine shield deposits at Site 953 (Unit V) are 49 $m$ thick and consist of several hundred, very thin sandy to silty turbidite beds, $1-40 \mathrm{~cm}$ thick, composed of variable amounts of dominantly tachylitic and minor altered vesicular quench shards and biogenic debris.

At Site 955, P1 syn-ignimbrite tephra is underlain by $32 \mathrm{~m}$ of nannofossil clay-mixed sedimentary rocks, with thin layers of basaltic detritus at the base of some foraminifer-rich turbidites, probably representing eroded subaerial lavas.

The upper $\sim 47 \mathrm{~m}$ of the submarine basaltic shield sequence at Site 956 consists dominantly of two major debris-flows deposits interlayered with foraminifer and nannofossil ooze, and, toward the top, basaltic volcaniclastic sandstones. A basal 80-m-thick debrite is charac- terized by abundant angular clasts of basalt of both subaerial and submarine derivation, is rich in clay-rich matrix, and contains few sideromelane shards. It is overlain by $\sim 2 \mathrm{~m}$ of xenocryst-rich sands.

Thick debris-flow deposits of the submarine basaltic shield phase, especially those at Site 956, are well reflected in the physical logs. The transition from the shield to the volcaniclastic sediments correlative to the Mogán Formation is characterized in the logs at all three sites by abrupt decreases in density, sonic velocity, and resistivity and by a sharp increase in $\mathrm{K}$, Th, and $\mathrm{U}$ derived from the total natural gamma-ray $\log$.

\section{The Rhyolitic, Trachytic, and Trachyphonolitic Volcaniclastic Sediments}

The sediments correlated to the Mogán and Fataga lithostratigraphic intervals on Gran Canaria contain numerous volcaniclastic beds composed of silt- to sand-sized, less commonly lapilli-sized, volcanic materials, chiefly glass shards, fragments of variably welded tuff, pumice, and crystals, and abundant neritic skeletal debris. The corresponding volcaniclastic lithostratigraphic intervals, $452 \mathrm{~m}$ thick at Site 953, $193 \mathrm{~m}$ thick at Site 955, and $194 \mathrm{~m}$ thick at Site 956 were subdivided aboard into three (Site 953) and two (Sites 955 and 956) lithologic subunits. The lowermost subunits at all three sites are correlated with the fallout tephra layers and ignimbrite cooling units of the Mogán Group on Gran Canaria (14-13.3 Ma), whereas the volcaniclastic layers of the one to two upper subunits are correlated with the Fataga Group (Fig. 9). The volcaniclastic turbidites in the time interval from 14 to $\sim 11.5 \mathrm{Ma}$ were subdivided into more than 100 volcaniclastic units, most of them $<20 \mathrm{~cm}$ thick, but layers up to $2 \mathrm{~m}$ thick make up $10 \%-20 \%$ of all volcaniclastic units at Holes $953 \mathrm{C}$ and 956B.

The lithoclasts, chiefly tachylitic and crystallized basalt, represent mainly eroded shield basalts and are especially common at Site 953, seaward of the more strongly eroded older northern flank of Gran

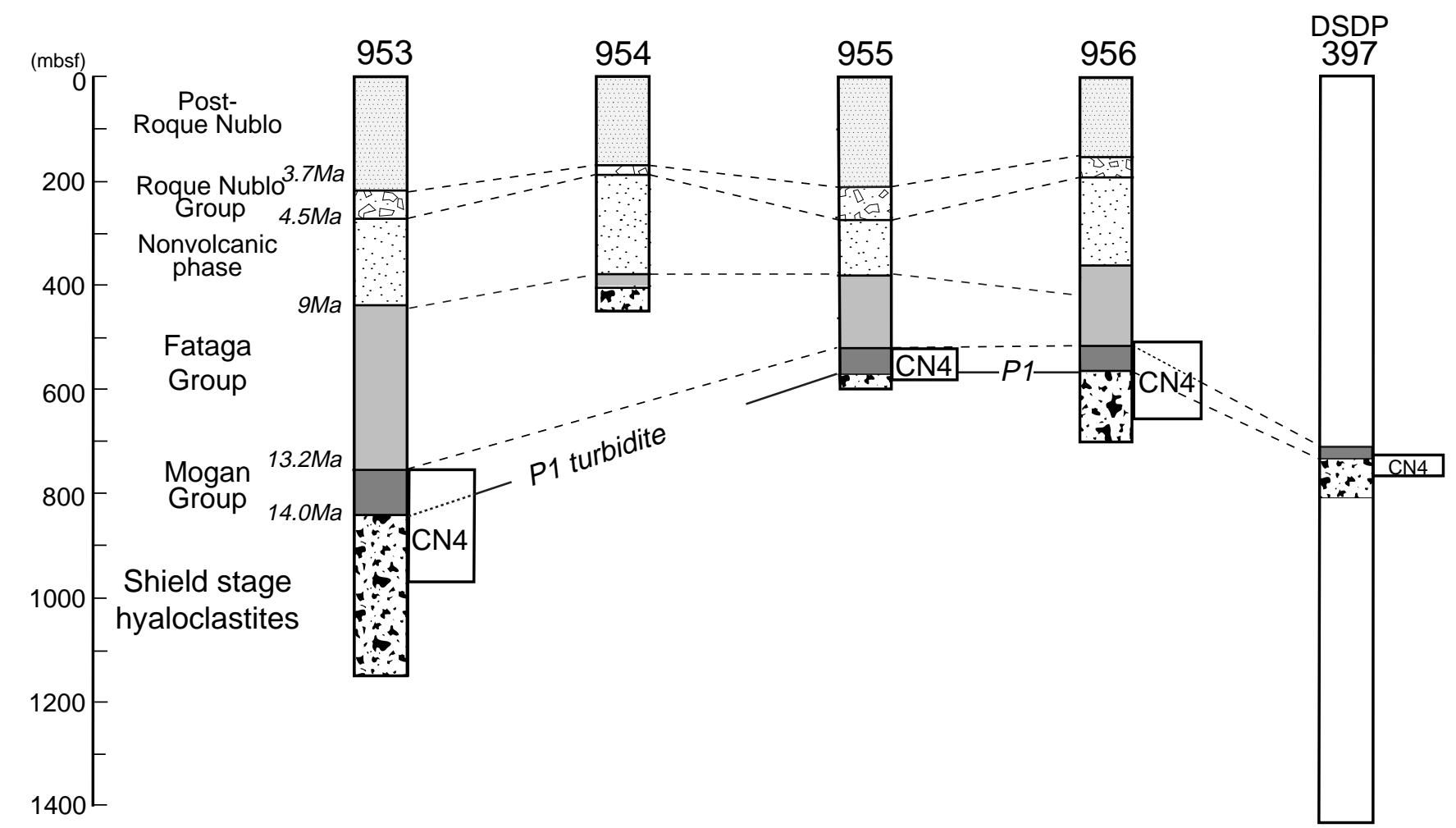

Figure 8. Stratigraphic sections and correlation of ODP Sites 953, 954, 955, and 956, and DSDP Site 397. The syn-ignimbrite turbidite P1 (13.9 Ma) is the common level at Sites 953, 955, and 956, approximated by DSDP Core 47-397-77, whereas the age of the basal basaltic breccia at Site 954 is uncertain. The approximate depth range of nannofossil Zone CN4, which covers most of the Mogán stratigraphic interval, is also shown. 


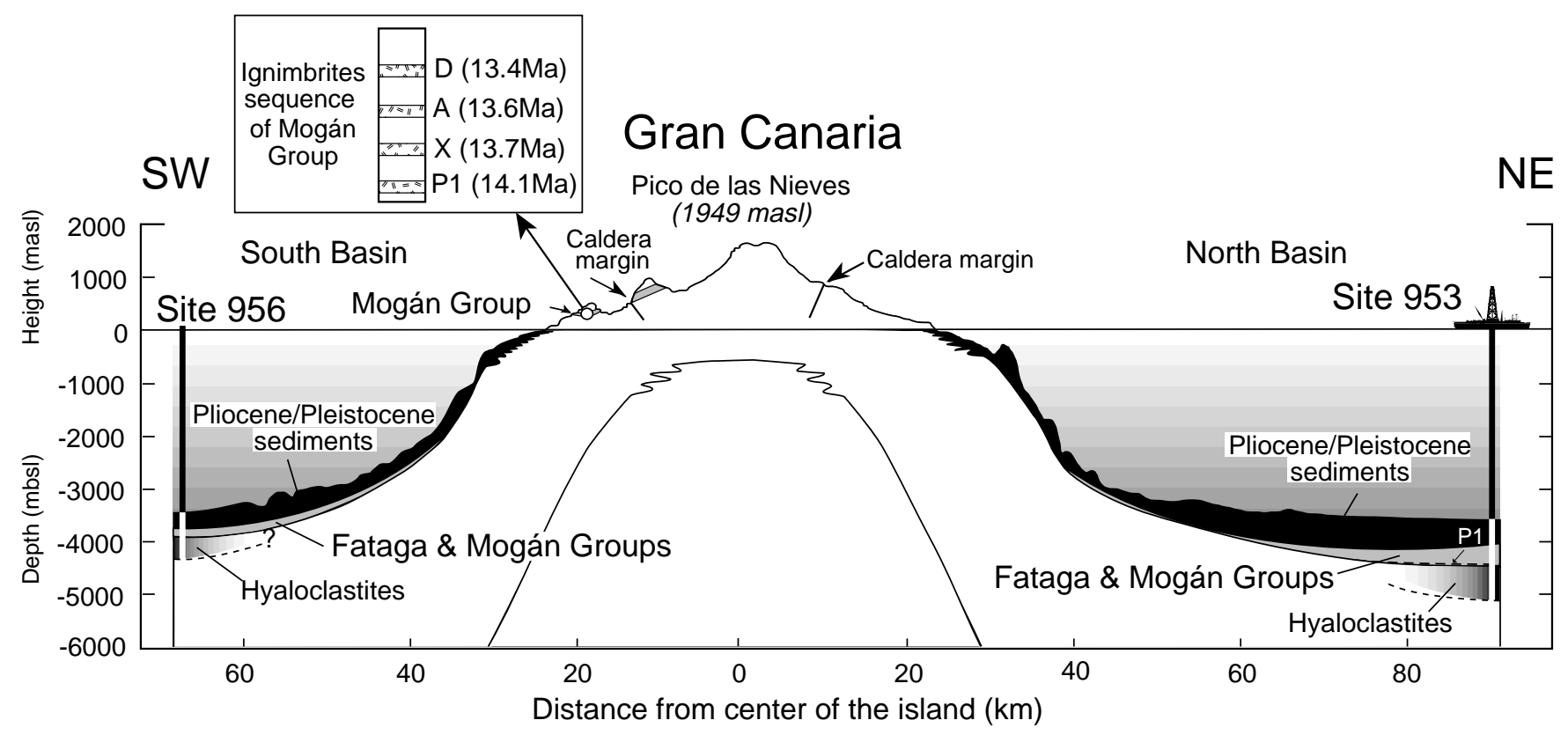

Figure 9. Cross section through Gran Canaria and an adjacent volcanic apron showing Sites 953 and 956, the southern mapped and northern inferred caldera margin on the island, and four characteristic ignimbrites, most of them having been identified as syn-ignimbrite turbidites in the drilled sections at Sites 953 , 955, and 956.

Canaria. The bioclasts consist mainly of unfilled planktonic foraminifers and nannofossil ooze in the highly vitric layers, whereas filled planktonic foraminifers, benthic foraminifers, and a variety of shallow-water calcareous and siliceous fossils and littoral skeletal debris are common in the coarser basal parts of syn-ignimbrite tephra layers and in reworked epiclastic volcaniclastic layers.

Seven syn-ignimbrite volcaniclastic units have been correlated unequivocally among holes and with their parent subaerial ignimbrites, based on qualitative petrographic criteria of $\sim 150$ polished thin sections and quantitative criteria based, in turn, on electron microprobe analysis of glass shards and the main phenocrystic minerals (feldspar, pyroxene, amphibole, and phlogopite), X-ray fluorescence analysis of 30 bulk subaerial tuff samples, and shipboard reanalysis of rock powders of major volcaniclastic layers in the time interval 14-12 Ma (Sumita and Schmincke, Chap. 15, this volume).

\section{The Major Gap in Volcanic Activity}

The amount of volcanic material deposited during the time interval of $\sim 9-5 \mathrm{Ma}$ at all four sites (lithologic Unit III at all four sites) is extremely small, probably $<5 \%$ of the total volume in each section (Schmincke, Weaver, Firth, et al., 1995; Schneider et al., Chap. 17, this volume). Volcanic particles are fine sand to silt in size and are entirely erosional in origin, mainly of the lava flows and ignimbrites of the Fataga Group and the basaltic shield. An abrupt decrease in K, $\mathrm{U}, \mathrm{Th}$, and, to a lesser degree, resistivity in the logs also reflects the pronounced decrease in supply of volcaniclastics in the volcanic gap.

\section{Roque Nublo Group Deposits}

A short-lived influx of coarse tuffs and lapillistones with very poor recovery in the mid-Pliocene (4.3-3.4 Ma) marks the transition from Unit III to Unit II and coincides with the Roque Nublo phase (about four cores $[\sim 40 \mathrm{~m}]$ at Site 953; approximately two cores [roughly $20 \mathrm{~m}$ ] at Site 954; and approximately four cores [40 m] at Site 956). The volcaniclastic sandstones in Cores 157-953C-7R and $8 \mathrm{R}$ differ significantly in their petrography from those at Site 954. Generally, angular to subangular particles are composed of domi- nantly tachylite and fine-grained crystallized basalt and as much as $50 \%$ of completely altered vesicular particles. Some units (e.g., Sample 157-953C-9R-3, 71-75 cm) are also rich in amphibole phenocrysts. Coarse, poorly recovered lithified tuffs and fine-grained lapillistones in Cores 157-954B-11R (177 mbsf) through 12R (188 mbsf) represent mostly well-rounded, almost exclusively clinopyroxenerich and olivine-poor basaltic rocks and minor Fataga trachyphonolites. The matrix is dark brown clay, and the pores are partially filled with phillipsite.

\section{Felsic Tephra Layers From Tenerife}

About 70 trachytic to phonolitic fallout tephra layers recovered at Holes 953A, 954A, and 956A consist chiefly of glass shards, highly vesicular pumice, and 1 to $10 \mathrm{vol} \%$ phenocrysts, dominantly alkali feldspar. They range in age from 0.3 to $3 \mathrm{Ma}$ and are interpreted to represent explosive eruptions on Tenerife. They are most numerous and thickest at Hole 956A, the site closest to Tenerife. The composition of glass shards changes from trachytic to phonolitic with time.

\section{CHEMICAL AND MINERALOGIC EVOLUTION}

The major element and trace element composition of whole rocks, fresh glass and mineral separates, and glass inclusions in phenocrysts was determined by microprobe, ionprobe, and synchrotron microprobe analyses in several studies in this volume (Sumita and Schmincke, Chap. 15; Schmincke and Segschneider, Chap. 12; Gurenko and Schmincke, Chap. 25; Gurenko et al., Chap. 22; Carey et al., Chap. 13; Schneider et al., Chap. 17; and Wallace, Chap. 24).

\section{Chemical Evolution}

The basaltic volcaniclastic rocks are a composite of rock and mineral constituents varying in degree of crystallinity, alteration, and sites of origin and parent basalts. Moreover, admixture of skeletal debris, matrix, and cement further complicates the interpretation of whole-rock analyses. The important chemical parameters, disregard- 
ing the concentrations of mobile elements such as $\mathrm{Ca}, \mathrm{Mg}, \mathrm{K}, \mathrm{Na}, \mathrm{Rb}$, $\mathrm{Sr}$, and $\mathrm{Ba}$, resemble those of the subaerial basalts quite well (Schmincke and Segschneider, Chap. 12, this volume). Ratios of the incompatible and immobile trace elements $\mathrm{Nb}$ and $\mathrm{Zr}$ are remarkably constant and suggest that the melting conditions did not change appreciably during the evolution of the shallow submarine to subaerial stages nor between eastern and western Gran Canaria (Fig. 10).

At Sites 953 and 956, there is a clear change in time from more primitive Ni- and $\mathrm{Cr}$-rich basalts, most pronounced in Unit VII (Hole 953C), to more evolved basalts, as best shown by the composition of fresh glass lapilli in Subunit V (Hole 956B). These deposits are directly related to volcanic eruptions, whereas lithic debris-flow deposits, such as those between 600 and 704 mbsf in Hole 956B or the 50$\mathrm{m}$-thick turbidite succession at the top of the basaltic sequence in Hole 953C, contain highly mixed assemblages of basaltic clasts.

The volatile elements $\mathrm{H}_{2} \mathrm{O}, \mathrm{CO}_{2}, \mathrm{~S}, \mathrm{~F}$, and $\mathrm{Cl}$ were measured in melt inclusions in clinopyroxene ( $\mathrm{Cpx}$ ), olivine (Ol), and feldspars by several workers (Hansteen and Gurenko, Chap. 23; Gurenko and Schmincke, Chap. 25; Wallace, Chap. 24; Sumita and Schmincke, Chap. 15; Schmincke and Sumita, Chap. 16; Rodehorst et al., Chap. 18; all this volume). The data on fluid inclusions from basaltic rocks agree with those published recently by Gurenko et al. (1996) in that $\mathrm{CO}_{2}$ is the dominant volatile phase, with $\mathrm{H}_{2} \mathrm{O}$ being absent.

$\mathrm{H}_{2} \mathrm{O}$ concentrations in melt inclusions of pyroxenes and olivines in samples from lithologic Unit VII (Hole 953C) and lithologic Unit IV (Hole 956B) determined by infrared spectroscopy (Wallace, Chap. 24, this volume) and ionprobe (Gurenko et al., Chap. 22, this volume), are low, ranging from 0.08 to 0.23 . These values are close to the $\mathrm{H}_{2} \mathrm{O}$ concentration in melt inclusions in olivine from subaerial shield basalts of Gran Canaria (Gurenko et al., 1996) and correspond to the lowest $\mathrm{H}_{2} \mathrm{O}$ defined for MORB and ocean-island basalt magma. $\mathrm{H}_{2} \mathrm{O}$ concentrations in clinopyroxene-hosted melt inclusions from Site 956, where the basalts are more evolved, are higher (0.40.85 [Gurenko et al., Chap. 22, this volume] and 1.2-1.4 wt\% [Wallace, Chap. 24, this volume]). Gurenko et al. (Chap. 22, this volume) calculate concentrations of carbon dioxide in the parental magmas between 0.17 and $0.28 \mathrm{wt} \% \mathrm{CO}_{2}$, very similar to values of 0.1 and 0.35 measured by infrared spectroscopy by Wallace (Chap. 24, this volume). Wallace argues that the picritic magmas crystallized at very low pressures ( $500 \pm$ bars), equivalent to 1 to $3 \mathrm{~km}$ depth beneath the subaerial Miocene volcanic edifice of Gran Canaria and argues that the picritic magmas were sufficiently $\mathrm{CO}_{2}$-rich to be positively buoyant relative to shallow-reservoir magma. Gurenko et al. (Chap. 22, this volume), who also determined trace element concentrations in melt inclusions by ionprobe and showed that the magma resulted from the melting of a garnet-bearing source, argued that crystallization of primary magma occurred at a pressure of $1-5 \mathrm{~kb}$, which is similar to pressures deduced by Freundt and Schmincke (1995b).

Hansteen and Gurenko (Chap. 23, this volume) studied the concentration of $\mathrm{S}, \mathrm{Cl}$, and $\mathrm{F}$ in olivine- and clinopyroxene-hosted melt inclusions from hyaloclastites from Holes 953C and 956B. Significant spreads in $\mathrm{S}$ and $\mathrm{Cl}$ concentrations (200-2580 ppm S; 120-930 $\mathrm{ppm} \mathrm{Cl}$ ) and the lack of correlation between $\mathrm{S}$ and $\mathrm{Cl}$ and $\mathrm{MgO}$ and $\mathrm{P}$ suggest degassing of the magmas before eruption. Gurenko and Schmincke (Chap. 25, this volume) found that vesiculated sideromelane shards from Pleistocene volcaniclastic sediments from Holes 953C, 954B, and 956B are characterized by low S concentrations and are interpreted to have formed by pyroclastic activity on

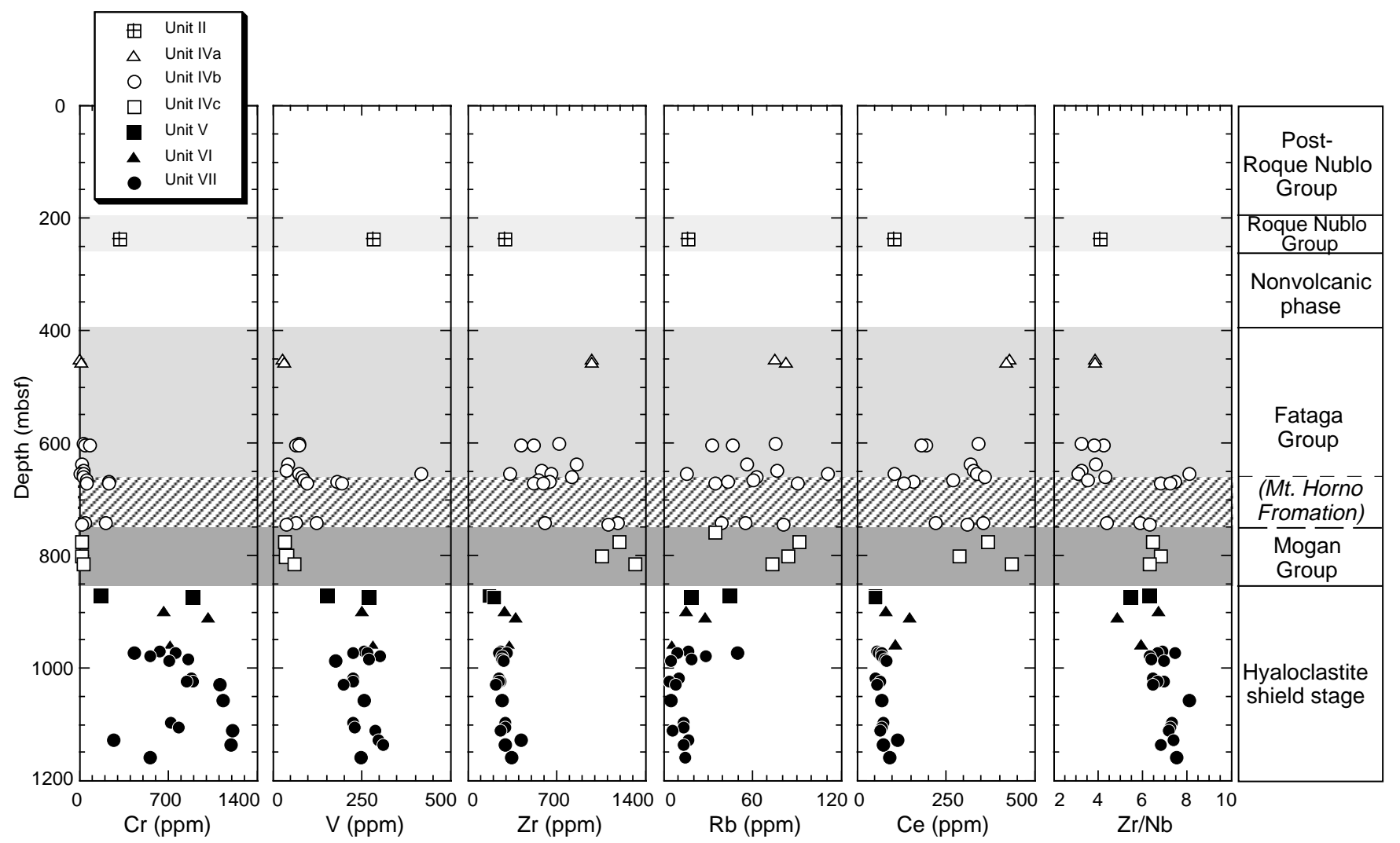

Figure 10. Stratigraphic plot of selected trace element concentrations and $\mathrm{Zr} / \mathrm{Nb}$ ratios of basaltic (solid symbols) and trachytic, rhyolitic, and trachyphonolitic whole rock samples (open symbols), and Roque Nublo intermediate rock of bulk volcaniclastic rocks and large rock fragments from Hole 953C, using analyses made aboard ship. Volcaniclastic turbidites compositionally intermediate between Mogán and Fataga (M. Horno Formation) are particularly abundant at Site 953. 
land or in shallow water before transport into deep water. Conversely, vesicle-free blocky shards have $S$ concentrations ranging from 0.05 to $0.13 \mathrm{wt} \%$, suggesting submarine eruptions at moderate water depths. Some of the nonvesiculated sideromelane glasses drilled at Sites 953 and 954 are believed to be caused by Pleistocene submarine basaltic eruptions north of Gran Canaria.

\section{Mineralogic Evolution}

The most common phenocryst phase in the basaltic rocks of the island, including basanite and nephelinite, is titanaugite; in some rocks, it is olivine. Plagioclase (Pl) occurs in the more evolved threephase basalts, which are minor in volume. Clinopyroxenes, feldspar phenocrysts, and even most glass shards from Leg 157 and DSDP Sites 369 and 397 are generally fresh in all evolved tephra layers as old as $14 \mathrm{Ma}$. The phenocryst assemblage in the clasts and matrixmainly $\mathrm{Cpx}$ (augite) and $\mathrm{Ol}\left(\mathrm{Fo}_{83-88}\right)$ but also minor $\mathrm{Pl}$ —of the basaltic hyaloclastites and breccias is typical of mildly alkalic basalts and changes with depth at both sites.

\section{Olivine}

Some olivine crystals within glass shards in the highly altered hyaloclastites in the lower part of Unit VII (Hole 953C) are only partially altered. Their composition ranges from $\mathrm{Fo}_{80-90}$ (Gurenko et al., Chap. 22; Schmincke and Segschneider, Chap. 12, both this volume).

\section{Pyroxene}

Strictly speaking, all single crystals in the volcaniclastic deposits are xenocrysts, with the exception of phenocrysts in volcanic clasts. It is, however, useful to make a distinction between single crystals that are essentially identical to phenocrysts in clasts (i.e., within synignimbrite tephra layers) and foreign crystals that belong to different lithostratigraphic intervals. Obviously, there is a complete range of xenocrysts that appear to have been incorporated by one syn-ignimbrite turbidite from a preceding tephra unit differing only slightly in composition from xenocrysts derived on land or by scouring of turbidite flows during transit under water from a different formation. Many authors have identified the alteration-resistant clinopyroxene xenocrysts as the most obvious indicator of erosion of the shield basalts and/or Pliocene and Pleistocene mafic series in the younger sediments (Schneider et al., Chap. 17; Freundt and Schmincke, Chap. 14; Sumita and Schmincke, Chap. 15; Gurenko and Schmincke, Chap. 25; Schmincke and Segschneider, Chap. 12, all this volume).

Greenish clinopyroxenes in the trachytic rhyolitic and trachyphonolitic units are distinguished from the basaltic clinopyroxene by being distinctly depleted in $\mathrm{Mg}, \mathrm{Al}, \mathrm{Cr}, \mathrm{Ca}$, and $\mathrm{Ti}$ and by being richer in $\mathrm{Na}, \mathrm{Fe}, \mathrm{Mn}$, and $\mathrm{Si}$. Aegirine-augites are rare, but aegirines, characterized by a deep green color and derived from fully crystallized ignimbrites and lava flows, are common in Miocene and younger sediments. Hypersthene is most common in tephra units corresponding to the lower Mogán stratigraphic interval. Enstatite is rare.

\section{Feldspars}

Plagioclase compositions range from labradorite-andesine in the pl-phyric basalts in the upper volcaniclastic rocks of Hole 956B (Cores 157-956B-43R through 45R), whereas compositions close to albite occur in some of the volcaniclastic units that are correlative to the lower Mogán Formation. Anorthoclase is the dominant phenocryst phase in the trachytic, rhyolitic, and phonolitic rocks on both Gran Canaria and Tenerife. These feldspars are stable in the sediments and hence are the chief mineral phase in the felsic volcaniclastic sediments. Feldspar compositions proved very valuable in characterizing and stratigraphically subdividing the main Miocene felsic volcaniclastic intervals (Sumita and Schmincke, Chap. 15, this volume).

\section{Amphibole and Phlogopite}

Amphibole is a common mafic phase in evolved rocks from the Mogán Group and in moderately to strongly evolved rocks erupted during the Roque Nublo volcanic phase; however, it is rare in the trachyphonolites from the Fataga Group and on Tenerife.

The composition of amphiboles varies systematically. Those derived from mafic and peraluminous-evolved rocks in the lower Mogán are calcic amphiboles, whereas those from the peralkaline trachytes to rhyolites are dominantly edenites and richterites.

The amphiboles from the exotic sandstones above the basal debrite at Hole 956B, which also occur as sporadic xenocrysts higher up in the section, differ drastically from all Gran Canaria amphiboles by being practically free of $\mathrm{F}$ and lower in titania. This compositional contrast underscores our interpretation (Schmincke and Segschneider, Chap. 12, this volume) that they were derived from a plutonic source, perhaps La Gomera or Fuerteventura. The marginal alteration of amphibole and phlogopite is likewise thought to have happened during deuteric cooling in plutonic rocks because all amphiboles derived from the volcanic rocks on Gran Canaria are fresh.

Dark mica, common in volcaniclastic rocks representing micabearing rocks on land, chiefly the Fataga Group, and those in ash layers correlated with Tenerife are all phlogopites. Mica is also common-but not abundant-in hyaloclastites at Site 956 and also in the exotic sandstone at this site. These micas differ significantly from those derived from Gran Canaria and Tenerife by having very low concentrations of $\mathrm{F}$ and $\mathrm{Ti}$. Unless there are mica-bearing plutonic rocks hidden in the core of Gran Canaria, these micas must have been derived from neighboring islands, such as La Gomera, whereas those at Site 953 may have been derived from Fuerteventura. Because of their low settling rate, these micas apparently were commonly suspended in the water column off the west coast of Fuerteventura and the east coast of La Gomera and, thus, became incorporated into the hyaloclastites generated during the submarine growth of Gran Canaria.

\section{Accessory Phases}

Zircon, titanite, and chevkinite inclusions in amphibole are diagnostic phases for a particular ignimbrite or a small number of compositionally characteristic ignimbrites and fallout tuffs on land. Because of their resistance to alteration, their occurrence in volcaniclastic layers has been most useful in interhole and marine-land correlations.

\section{Alteration}

One of the objectives of Leg 157 was to study the influence of volcaniclastic, glass-rich sediments, interbedded and mixed with organic-poor and organic-rich sediments, on the composition of the pore waters to assess chemical fluxes between volcanic glass comprising basaltic, phonolitic, and rhyolitic compositions and pore solutions at different distances from Gran Canaria (i.e., different proximities to heat sources in the interior of the island). The glassy nature of volcaniclastic debris makes it an especially sensitive indicator of diagenetic processes.

Sideromelane in the basal hyaloclastite intervals is generally replaced by smectite, as shown macroscopically by the green color of the basaltic shield sections at all sites. Fresh glassy cores of nonvesicular glassy lapilli of slightly evolved compositions occur, however, in the uppermost debris flow at Hole 956B (Cores 157-956B-45R and 44R). Fresh sideromelane shards occur as hyaloclastites and are mixed with rhyolitic ashes in the Mogán interval. Their freshness is interpreted as a result of rapid sedimentation. Zeolites, mostly phil- 
lipsite, less common analcime, natrolite, and gmelinite, and minor aragonite and calcite occur in the pore space between shards and lapilli and in rare veins. In addition to $\mathrm{H}_{2} \mathrm{O}, \mathrm{Mg}$ and, to a lesser extent, alkalis are invariably added to the rocks, whereas all rocks show massive $\mathrm{Ca}$ loss.

Alteration was chiefly diagenetic, but some hydrothermal effects are reflected in higher temperature mineral phases and fluid inclusions (Lindblom and Gerard, Chap. 26, this volume). Proximity to the island and depth of burial do not appear to have influenced the alteration of glass-bearing sediments, presumably because hydrothermal circulation was largely restricted to the core of the island. Fluid inclusions in vein aragonite in the basal basaltic breccia drilled in Hole 954B were hot $\left(185^{\circ}-284^{\circ} \mathrm{C}\right)$ and saline $(4.6$ and $15 \mathrm{wt} \% \mathrm{NaCl}$ equivalent). Otherwise, fluid inclusions and mineral stabilities indicate lower maximum temperatures $\left(100^{\circ}-150^{\circ} \mathrm{C}\right)$ and lower salinities of hydrothermal solutions at Sites 953 and 956.

A surprise was the abundance of fresh glass of trachytic-rhyolitic composition in volcaniclastic sediments correlated to the Mogán Group, whereas trachyphonolitic volcaniclastic sediments correlated to the Fataga phase contain less fresh glass and are moderately to thoroughly zeolitized, chiefly to natrolite and phillipsite. This more intense alteration in the younger volcaniclastic sediments is explained by the less strongly polymerized structure of the phonolitic compared to the rhyolitic glasses-which are, however, dominantly of peralkaline pantelleritic to comenditic composition-and by the longer exposure to seawater of individual sedimentation units, because eruptive intervals during Fataga time were generally longer.

Diagenetic processes are well reflected in pore-water profiles that varied widely between sites (Schmincke, Weaver, Firth, et al., 1995). Site 953 is dominated by fluid/rock interaction between pore waters and volcanic glasses of different composition and minerals. Site 954 displays large geochemical anomalies associated with carbonated pore waters. At Site 955 , organic matter contained mainly in slumped sediments derived from the northwest African margin has driven intense sulfate reduction and methanogenesis at shallow depths, whereas the deeper part of the section contains saline brines, possibly related to leached evaporites. The rate of preservation of organic matter, a complex mixture of marine and terrestrial-derived material, is surprisingly high (Littke et al., Chap. 21, this volume). Hydrogen index values calculated from Rock-Eval pyrolysis data are as high as those in the upwelling sediments along the continental slope off northwest Africa. Part of the organic matter is preserved because it was transported in mass flows, leading to minimum aerobic degradation. Anomalously enhanced levels of organic matter maturation in the vicinity of the Canary Islands were not detected from the organic, geochemical, and organic-petrologic data, even in the deeper samples.

\section{EVOLUTION OF GRAN CANARIA AS DOCUMENTED IN THE DRILL CORES}

\section{The Seamount Stage}

The hyaloclastite debris flows of the 190-m-thick basal lithologic Unit VII at Site 953, in which the shards are dominantly dense and contain pebbles of possible subaerial derivation at the base of the $\sim 16$ debris flows are similar to the debris flow V3 at Site 397 (DSDP Leg 47A; Schmincke and von Rad, 1979). This suggests that an eruption occurred at moderate water depth (i.e., more than $\sim 500 \mathrm{~m}$; Staudigel and Schmincke, 1984) and that some subaerial activity was taking place near the growing seamount, thereby strengthening the evidence that Gran Canaria is composed of several shield volcano complexes of different ages. Application of the vesicle volume barometer (Moore, 1970b) is not straightforward because of the change in composition from picritic to moderately evolved alkalic lavas and, therefore, volatile composition with time, and particularly because of the transfer of volcaniclastic deposits formed at shallow depth to the deep sediment basins. Nevertheless, none of the hyaloclastites of Unit VII was found to contain shallow-water skeletal debris of the type commonly encountered in the overlying syn-ignimbrite turbidites, strongly suggesting submarine eruption below wavebase. Vesicularity of sideromelane shards increases in an irregular manner upward at Sites 953 and 956, most likely reflecting decreasing water depth of eruption. The lack of interbedded nonvolcanic sediments in lithologic Unit VII (Site 953) indicates very high sedimentation rates for this phase of submarine deposition and, therefore, high rates of volcanic production.

Coarser grained breccias and hyaloclastite debris-flow deposits at Site 953 (lithologic Unit VI) are interpreted to reflect the change from shallow submarine to emergent volcanism, with the breccias possibly representing collapsed lava deltas formed at the island/shore interface.

The basaltic volcaniclastics in the upper part of lithologic Unit V in Hole 956B, composed largely of extremely vesicular ash and lapilli of evolved basalt, are thought to have formed during very shallow-water explosive eruptions (Schmincke and Segschneider, Chap. 12 , this volume).

The age of the boundary between early and middle Miocene is given as $\sim 16.4 \mathrm{Ma}$ in Berggren et al. (1995), with the boundary between calcareous nannoplankton Zones $\mathrm{CN} 3$ and $\mathrm{CN} 4$ being roughly at 15.6 Ma (i.e., almost $1 \mathrm{~m}$.y. younger). In Schmincke, Weaver, Firth, et al., (1995), the CN3/CN4 boundary is practically equated with the early Miocene/middle Miocene boundary, with CN3 being the oldest nannofossil zone identified in Holes 953C and 955A, but not in 956B. Since the lowermost $190 \mathrm{~m}$ in Hole 953C (Unit VII) consists exclusively of very rapidly deposited hyaloclastite debris flows without any biogenic sediments, we suggest that the bottom of Hole 953C is not much older than 15.6 Ma (i.e., middle Miocene, as at the bottom of Holes 956B and 955A), an interpretation that has major implications for sedimentation and magma production rates.

\section{Emergence of Gran Canaria (Lithologic Unit V, Holes 953C and 956B)}

The nature of the volcanic and nonvolcanic sediments below the precise time horizon of syn-ignimbrite turbidite P1 at Sites 953, 955, and 956 clearly reflects the migration of basaltic shield activity from north-northeast to southwest (Fig. 11). Significant volcaniclastic sediments representing subaerial erosion of the shield at Site 953 have been studied in detail by Carey et al. (Chap. 13, this volume). Computer-assisted fractal analysis of sideromelane grain morphologies in these sediments shows an increase in morphological complexity with decreasing age, which, along with an increase in the modal abundance of tachylite with decreasing age, is interpreted by Carey et al. (Chap. 13, this volume) to represent a decreasing role of deeper, submarine volcanism as the source of clastic particles. The strongly mixed lithologies of the turbidites and the occurrence of common, rounded microcrystalline basalt fragments suggest to them that many of the layers were formed by the slumping of volcaniclastic material from shallow-water following accumulation of material from erosion of subaerial products, entry of lava flows into the sea, and shallow submarine eruptions. A medium frequency of one flow event every $2000 \mathrm{yr}$ was determined from the thickness and accumulation rate of interbedded pelagic sediment in Unit V. On land, basaltic volcaniclastics ranging from fanglomerates to mudstones of the $\sim .50-\mathrm{m}$ thick Barranco de Balos formation in southeastern Gran Canaria (Schmincke, 1994) are probably the stratigraphic equivalent and possibly one of the sources for some of the late stage turbidites. Schmincke and Segschneider (Chap. 12, this volume) argue that the turbidites of this unit have formed dominantly by reworking of subaerial erosionally fragmented scoria cone lapilli and lava flows at times of strongly decreased volcanic activity in northeastern Gran Canaria. Conversely, Carey et al. (Chap. 13, this volume) infer high volcanic activity throughout this interval. 
A
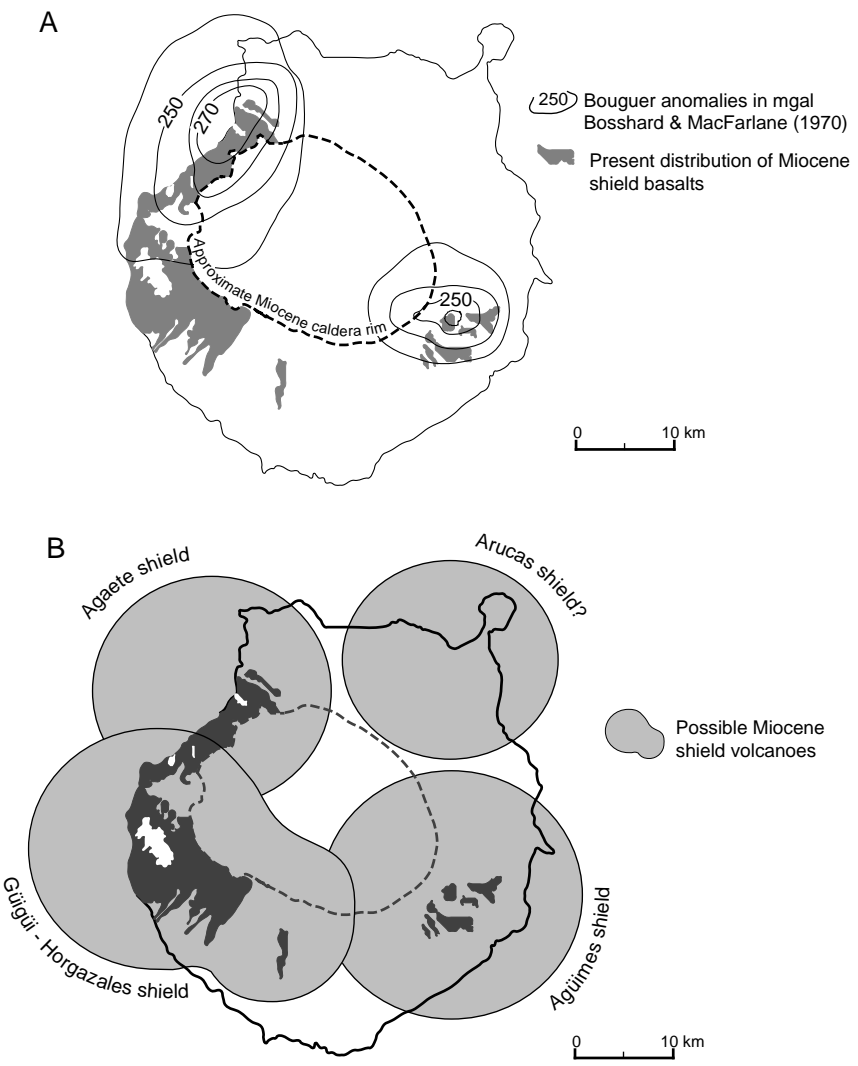

Figure 11. Schematic sketch showing present outcrop distribution of Miocene shield basalts on Gran Canaria (dark) and Bouguer anomalies in mgal. The drawing showing four shield volcanoes of different ages is highly speculative and based on land and drilling evidence as discussed in the text. The locations of Güigüi-Horgazales, Agüimes, and, to a lesser degree, Agaete shields, are well supported by field data, whereas the Arucas shield is highly conjectural.

The time interval believed to be represented by the turbidites of lithologic Unit V is estimated by Carey et al. (Chap. 13, this volume) to represent 0.5 m.y. As shown by the high sedimentation rates for the correlated time-equivalent lithologic Units IV, which are about twice as high for Hole 953C compared with Hole 956B, the drilled area northeast of Gran Canaria was located in a major depositional fan. Consequently, the supply rate of volcanic material was high in Hole 953C compared with the other sites. The biostratigraphic evidence for the beginning and end of lithologic interval $\mathrm{V}$ is too poorly constrained, however, to allow an estimate of the length of time during which these sediments were deposited, and we speculate, based on the generally high sedimentation rates in the area, that the amount of time represented by lithologic Unit V could be as low as 0.2 m.y., or perhaps even lower.

The upper hyaloclastites of Unit V at Site 956 are time equivalent to Unit V at Site 953, but they record chiefly active submarine and subaerial volcanism at a time when dominantly erosional detritus was supplied to Site 953. The contrasting deposits of the basaltic shield stage at Sites 953 and 956 agree with the land evidence showing that erosional downcutting of the shield basalts in southwestern Gran Canaria was minimal before eruption of ignimbrite P1. Apparently, basaltic volcanic activity in this area continued to just before eruption of ignimbrites, greatly reducing effective erosional fragmentation.

Only thin layers of basaltic sandstone and siltstones, but no hyaloclastites, were drilled below syn-ignimbrite turbidite P1 at Site 955, situated at the edge of the volcanic apron (Funck, 1996), presumably because erosion prevailed in eastern and southeastern Gran Canaria at this time, and sediment transport during erosional intervals was much more channelized than during volcanically active periods. However, there is no evidence from lithologic Units V and IV that Site 955 was situated close to a main distribution channel. The flank collapse debris-flow deposits are discussed in the "Transport and Dispersal of Volcaniclastic Sediments" section (this chapter).

\section{The Ignimbrite-Derived Felsic Turbidites}

More than $\sim 1000 \mathrm{~km}^{3}$ of felsic magma was erupted on land during the Mogán and Fataga stratigraphic intervals. This figure has to be roughly doubled because of the large volume of correlative submarine volcaniclastic layers drilled. A maximum assumption would be to interpret the entire noncored intervals in the main felsic volcaniclastic sections (Units IV in Holes 953C, 955A, and 956B) as volcanic, based on the fact that the volcaniclastic layers are coarser grained and less consolidated than the ooze sediments and, therefore, are likely to hide in the nonrecovered interval. The minimum assumption is based only on the recovered volcaniclastic and biogenic sediments, assuming that the nonrecovered intervals contain biogenic and volcaniclastic particles in the same ratio. The third possibility - to assume that the nonrecovered interval is entirely biogenic-is considered the least likely for the reasons stated above. Analysis of Formation MicroScanner data (Binard et al., Chap. 4, this volume) and of the chemical logs (Delius et al., Chap. 3, this volume) support the first assumption. For Unit IV at Site 953, for example, this results in 80\% (350 m) volcanics.

For each volcanic unit where thin sections were available, we have estimated the amount of biogenic debris, which again gives only approximate figures because the proportion in volcanic units can vary drastically. Taking these factors into account, we think that the organogenic background sedimentation both by hemipelagic sedimentation and turbidites represents no more than $\sim 50 \%$ of the upper volcanic apron drilled within the crude quadrangle defined by the drilling sites. Extrapolation beyond the drilling sites is difficult because, within certain limits, the sediment supply rate exerts a larger influence than the distance to the island. For example, Site 953 is the farthest from the island, yet its volcanic sedimentation rate was almost twice that of the other sites for the Miocene as well as for the Pliocene. When ODP Site 955, $50 \mathrm{~km}$ southeast of Gran Canaria, and DSDP Site 397 (DSDP Leg 47A), $100 \mathrm{~km}$ southeast of Gran Canaria, are compared with each other, the total thickness of evolved volcanic material - ash fallouts, syn-ignimbrite tephra-is estimated to have decreased from $\sim 40$ to $110 \mathrm{~m}$ at Site 955 to $\sim 10 \mathrm{~m}$ at DSDP Site 397.

Brown, blocky, dense, completely welded, and rounded partially welded tuff shards common in coarser tuffs and lapillistones are interpreted to have formed by quench fragmentation (thermal shock) and steam explosions as the hot pyroclastic flows entered the sea and subsequent fragmentation of cooling ignimbrite sheets forming cliffs along the shore (Sumita and Schmincke, Chap. 15, this volume). Post-eruption, erosional mixing is reflected in volcaniclastic layers that are well bedded, contain a larger amount of shallow-water skeletal debris and rounded basaltic lithoclasts, and vary widely in glass and mineral compositions.

The high-precision ages of the land ignimbrites (Bogaard and Schmincke, Chap. 11, this volume), coupled with the lithostratigraphic correlation, allow us to calculate more precise sedimentation rates in the interval between 14 and $13.3 \mathrm{Ma}$, which vary from 40 to $110 \mathrm{~m} / \mathrm{m}$.y. (Sumita and Schmincke, Chap. 15, this volume). They also help to calibrate the biomagnetostratigraphic time scale. Highresolution dating of the volcaniclastic and biogenic sediments correlated with well-dated rock bodies and entire formations on the islands of Gran Canaria and Tenerife was one the main aims of the VICAP drilling project. High-resolution correlation between formations on land and the drilled sediments was expected for (1) the interval between $\sim 14$ and 13.3 Ma for which most of the $\sim 15$ ignimbritic cooling 
units of the Mogán Group on land have been dated, some with a precision of few tens of thousands of years; (2) the phonolitic tephra layers of the Roque Nublo volcanic phase; and (3) the tephra layers correlated with the Las Cañadas/Pico de Teide volcanic complex on Tenerife. The chemical compositions of glass shards and phenocryst minerals in the tephra layers drilled and their lithostratigraphic correlation to the dated land deposits (Sumita and Schmincke, Chap. 15, this volume) form the backbone of the chronological subdivision of the cores, as based on physical ages.

The biostratigraphy of the sediments at Site 953 has been investigated in detail by combining both shipboard and land-based analyses, whereas the biostratigraphies for the other three sites are restricted to ship-based work. Brunner et al. (Chap. 9, this volume) provide a synthesis of the biomagnetostratigraphic framework. Bogaard (Chap. 19, this volume), who studied six fallout tephra layers and 16 heterolithologic volcaniclastic beds drilled in Holes 953A, 954A, and 956A, has noted in the 0-2 Ma stratigraphic interval that the ${ }^{40} \mathrm{Ar} /{ }^{30} \mathrm{Ar}$ ages of fallout ash layers are perfectly compatible with the age and sedimentation rate estimates from nannofossil and paleomagnetic chronostratigraphies.

Those tephra layers, for which several lines of evidence indicate a synchronous origin with their source ignimbrites on land ("synignimbrite turbidites"), provide the most interesting stratigraphic and chronological event deposits for comparison with the biomagnetostratigraphic data and the physical ages assigned to specific chrons and intervals of normal and reversed polarity. For example, the age at the boundary between calcareous nannofossil biochrons $\mathrm{CN} 4$ and $\mathrm{CN} 5$ is given as 13.6 Ma in the most recent revised Cenozoic geochronology and chronostratigraphy (Berggren et al., 1995). This boundary was identified near the top of Core 157-953C-64R, in the middle of Core 157-955A-56X, and near the top of Core 157-956B38R. Sblendorio-Levy and Howe (Chap. 8, this volume) found Sphenolithos heteromorphos, whose last occurrence (LO) defines the top, and Helicosphaera ampliaperta, whose LO defines the bottom of Zone CN4. If the identification of syn-ignimbrite turbidites A and D at Sites 953, 955, and 956 (Sumita and Schmincke, Chap. 15, this volume) and the single crystal ages of the Mogán ignimbrites reported by Bogaard and Schmincke (Chap. 11, this volume) are correct, then the boundary between nannofossil Zones CN4 and CN5 is $\sim 0.2-0.3$ Ma younger than the age reported in the literature.

Because the production of tephra layers in the Mogán time interval corresponds approximately with the land record, we expected to be able to correlate eight major volcaniclastic layers in the lower part of the Fataga interval to a major pulse of ignimbrite emplacement on land (the middle Fataga Formation) between 11.4 and $12 \mathrm{Ma}$. The biostratigraphic dating in all three holes suggests that the period of sedimentation of major syn-ignimbrite turbidites ends at $\sim 12 \mathrm{Ma}$. Because of the fairly detailed dating of the ignimbrites on land by the single-crystal ${ }^{40} \mathrm{Ar} /{ }^{39} \mathrm{Ar}$ method, we suspect that the biostratigraphic data for this interval are too old.

\section{The Nonvolcanic Interval}

The contrast between volcaniclastic apron sediments laid down during the nonvolcanic interval between $\sim 9$ and $5 \mathrm{Ma}$ (lithologic Unit III in all sites), when volcanic activity on Gran Canaria was practically absent with the over- and underlying sections, could not have been more extreme. Sediments with minor epiclastic volcanic debris drilled at Sites 953 and 954 were emplaced by low-density turbidity currents (Schneider et al., Chap. 17, this volume).

For several reasons, however, we cannot simply use the low accumulation rate at all sites as representative of the nonvolcanic sediments - chiefly nannofossil and foraminifer ooze-and extrapolate it to the younger and older sections with their higher contents of volcanic particles and thereby calculate the fraction of volcanic material in the entire volcanic apron. First, the mode of transport has varied sig- nificantly throughout the 15- to 16-m.y.-long evolution of Gran Canaria. For example, coarse biogenic littoral debris is commonly associated with various types of volcaniclastic turbidites and debris flows, chiefly those generated during entry of pyroclastic flows into the sea and what we interpret to be tsunami deposits (Schmincke and Sumita, Chap. 16, this volume). Another factor is the occurrence of thick layers of coarse-grained bioclastic sands during the Pleistocene, interpreted as having been generated dominantly during regressions at the time of glacial maxima.

Paleontologic data suggest rapid reworking of the epiclastic material to the basin (Schneider et al., Chap. 17, this volume). Distinctive changes in benthic foraminifer assemblages were detected between the volcanic gap and the overlying late Pliocene and Quaternary intervals of relative volcanic inactivity. Volcaniclastic turbidites from both intervals include the depth assemblage with species restricted to the upper slope (130-1000 m). However, only the volcaniclastic turbidites from the late Pliocene and Pleistocene epochs contain significant numbers of specimens from the broader depth zone that ranges from the shelf to the slope $(0-1000 \mathrm{~m})$. The change in upper bathyal faunas between the volcanic gap and the late Pliocene can be caused by either one or both of the following two mechanisms: (1) change in water-mass properties and structure caused by intensification of global glaciation beginning $\sim 2.8$ m.y. ago or (2) change in the benthic environment and style of sedimentation at bathyal and neritic depths. The assemblage changes are not an artifact of evolutionary extinctions or originations because all of the common species found in the volcanic gap are also found in the Quaternary.

\section{Roque Nublo Phase}

One of the surprises in drilling the clastic apron north and south of Gran Canaria was the paucity of volcaniclastic sediment within the stratigraphic interval younger than $\sim 4.5 \mathrm{Ma}$. The coarse grain size and, in part, the unconsolidated nature of the volcaniclastic sediments are believed to be the major reasons for the poor recovery of some coarse-grained deposits in this interval. Thus, the real thickness is probably much larger. The coarse-grained deposits are interpreted as submarine debris flows, continuing the huge debris-avalanche deposits recognized on the island. These coarse-grained sandstones and lapillistones deposited during the time interval between Sections 157-953C-7R-2 and 8R-1 and in Cores 157-954B-11R and 12R appear as a narrow band of high-amplitude reflectors mapped across the northern clastic apron by Funck (1996).

Many of the basalt clasts in the coarse-grained breccias could theoretically be derived from the shield lavas, although it is more likely that they are derived from Roque Nublo lavas, whose alkali basalts are indistinguishable from those of the Miocene shield lavas. Highly altered, formerly glassy clasts range from highly vesicular to nonvesicular, but the presence of microlite-rich clasts suggest derivation from quenched lavas, most likely widespread pillow lavas erupted $\sim 4 \mathrm{Ma}$, overlying a thick series of late Miocene sediments along the northeastern coast of the island.

\section{Tephra Layers Correlated With Las Cañadas/ Pico de Teide Volcanic Activity on Tenerife}

The felsic tephra layers in sediments younger than $\sim 3$ Ma are mostly classical fallout ashes with sharp bases and diffuse bioturbated tops but also include layers of pumice pebbles and mixed sediment beds. Deposits composed of, or containing, rounded pumice pebbles recovered at Sites 954 and 956 most likely represent the distal equivalents of pyroclastic flows and/or lahars that entered the sea at the southern shore of Tenerife, but these make up only a small part of the tephra layers. 
The significance of the felsic tephra layers related to Tenerife is threefold:

1. The greater thickness of fallout tephra layers at the southwestern Site 956 could indicate that paleowind directions resembled present-day ones. Correlation of the layers between sites, which would allow us to draw isopach maps and to infer more precise paleowind directions, is the subject of work in progress.

2. Explosive volcanic activity of the Cañadas/Teide volcano on Tenerife and, therefore, volcanic production rates were more continuous than has been interpreted from the land evidence (Marti et al., 1994). Previously postulated time gaps in volcanic activity on the island may be artifacts reflecting the poor preservation potential of ash-fall deposits on steep volcanic islands and the excellent preservation in the marine environment.

3. The change in composition from trachytic to phonolitic with time is thought to reflect changes in melting conditions at the source, most likely decreasing degrees of partial melting.

\section{Pleistocene Mafic Volcaniclastic Sediments}

Were it not for the coarse layers of "beach sand" in the Quaternary sediments at most sites and the felsic tephra layers from Tenerife, the sedimentation rates for lithologic Unit I would resemble those of the nonvolcanic period (lithologic Unit III). This is because of the unexpectedly small volume of volcanic clasts. The correlation of mixed biogenic-basaltic unconsolidated, coarse-grained volcaniclasts with distinct phases on Gran Canaria or on neighboring islands is not straightforward. The Quaternary volcanism on La Isleta, the peninsula at the northwestern tip of Gran Canaria, extends farther seaward, where the bathymetry shows young lava flows and submarine cones (Funck and Schmincke, in press). Submarine volcanism also occurred in the channel between Gran Canaria and Fuerteventura, where an $18-\mathrm{km}$ broad volcanic complex with two cones was detected. The sideromelane shards in these Quaternary sediments seem to reflect both derivation from subaerial detritus as well as true submarine activity at Site 953 off Gran Canaria, at Site 954 from Gran Canaria and Tenerife, and at Site 956 from Tenerife.

\section{TRANSPORT AND DISPERSAL OF VOLCANICLASTIC SEDIMENTS}

Factors that controlled fragmentation and volcaniclastic sedimentation in the apron include (1) direct volcanic activity such as entry of ash flows and lava flows into the sea, deposition of fallout ashes following explosive eruptions, and submarine eruptions; (2) indirect volcanic control, such as subaerial or submarine generation of large volumes of unconsolidated particles that formed large, temporary depots and subaerial and/or submarine slope failures, generating debris avalanches, debris flows, and turbidites; (3) tsunamis; (4) climate with two major effects: climatically governed sea-level changes and generation of abundant subaerial epiclastic sediments by erosion, especially during periods of higher rainfall; and (5) failure of heavily sedimented slopes independent of volcanic events.

\section{Deposits Reflecting Volcanic Events (Explosive Eruptions)}

Volcaniclastic sedimentation during the time interval 16-9 Ma was governed dominantly by direct and indirect volcanic processes, rather than by climate and erosion. It is not clear which of the debrisflow deposits and turbidites in the basaltic volcaniclastic sections are products of direct vs. indirect volcanic events. In other words, did sin- gle basaltic volcanic eruptions initiate mass wasting or did clastic material just accumulate on the island slopes until it became unstable and was transferred episodically to the sediment basins, with neither the transport nor the deposition being related to any eruption? That the hyaloclastite debris-flow deposits of Unit VII (Hole 953C) are not interrupted by mixed-sediment turbidites or hemipelagic sediments and that the (altered) sideromelane shards and lapilli are dominant in these deposits are taken as evidence for indirect control by volcanic eruptions via an intermediate depot center, from where rapidly accumulated particles were episodically destabilized and continued as sediment gravity flows into adjacent basins. The triggering of the 10m-thick uppermost debris-flow deposit (Core 157-956B-44R) in Hole 956B that contains the drop-shaped glassy lapilli and highly vesicular sideromelane shards may also be closely related in time to lava flows pouring into the sea in southwestern Gran Canaria.

The prominent coarser grained, vitroclast-rich felsic tuffs and lapillistones in lithologic Unit IV at Sites 953, 955, and 956 were probably emplaced dominantly by turbidity currents immediately following entry of ash flows into the sea along the gently sloping undissected southern shores of Gran Canaria and channelized into the mouth of large canyons in the northeastern part of the island. The precise correlation of many volcaniclastic layers from $68 \mathrm{~km}$ north to 60 $\mathrm{km}$ southeast of Gran Canaria over distances of $\sim 170 \mathrm{~km}$ and the more locally restricted occurrence of other layers or units have led us to think in terms of two contrasting dispersal patterns. We use the term "concentric sedimentation" for all those volcaniclastic deposits that record concentric dispersal from a nearly circular island largely independent of preexisting subaerial canyons (barrancos in Spanish), or submarine channels. We contrast this broad concentric with more "linear channeled dispersal."

Highly vitric silt-sized and sand-sized tuffs, commonly well sorted and largely devoid of lithic clasts and crystals that commonly directly overlie coarser grained tuffs or lapillistones, are interpreted as syn-ignimbritic that most likely represent the low-density fraction of turbidites elutriated from the main traction carpet during submarine transport and deposited as a series of thin, dilute turbidites subsequent to the main body. Some of these fine-grained tuffs contain open planktonic foraminifers and, in some fine-grained top ashes, a finegrained clay matrix in which the shards are embedded, contrasting with the coarse neritic, benthic foraminifers and filled planktonic foraminifers in the basal coarse-grained parts of turbidite units. Some of the coarse tuffs and lapillistones contain abundant pick-up clasts of pelagic sediments. All of these features suggest that the high-density turbidites-in which much more biogenic shallow-water debris was transferred to the deep sediment basins than in any nonvolcanic turbidites-were erosive, as also shown by their sharp, sometimes unconformable basal contacts. The low-density, weak ash turbidites became mixed with some of the clay stirred up by the high-density turbidites during the waning stage of these large events. These fine ash turbidites may also contain co-ignimbrite ashes, elutriated during emplacement of the ignimbrites on land or during entry into the sea and deposited in the sea, and abrasion in large pumice rafts, which are commonly observed after large eruptions and/or by interface-shearing of co-ignimbrite ash clouds traveling over the water surface.

\section{Deposits Reflecting Flank Collapse, Volcanic Slumps, and Debris Flows (Indirect Volcanic Events)}

Although the generation of large landslides on the Canary Islands has been suspected for more than $150 \mathrm{yr}$, the ubiquitous occurrence of landslides on the deep seafloor adjacent to oceanic islands was recognized only recently in the Hawaiian Island chain (Moore et al., 1989; Moore and Clague, 1992) by mapping of the seafloor with swath bathymetric and side-looking sonar systems (e.g., GLORIA), a discovery that greatly increased our understanding of the evolution of volcanic islands. The enormous scale of mass wasting — and the giant 
tsunamis they trigger-is evident from the GLORIA records, which reveal that giant slumps as much as $10,000 \mathrm{~km}^{3}$ in volume with blocks measuring as much as $30 \mathrm{~km}$ across occur around many of the Hawaiian Islands. These, in turn, have generated large proximal debris flows and distal turbidites that can be traced for several $100 \mathrm{~km}$ away from the source volcanoes (Lipman et al., 1988; Moore et al., 1989, 1994; Garcia and Meyerhoff Hull, 1994). Landslide deposits have been characterized largely by their submarine surface morphology and, in some cases, corresponding submarine and/or subaerial scars on the source islands.

Sedimentation rates around the Canaries are, in general, $>50 \mathrm{~m} /$ m.y., as shown by ODP Site 953, north of Gran Canaria (Schmincke, Weaver, Firth, et al., 1995), whereas average sedimentation rates along the Hawaiian Ridge are only $\sim 2.5 \mathrm{~m} / \mathrm{m}$.y. (Moore et al., 1994). Hence, large submarine landslide blocks around the Canary Islands would tend to become buried in sediments and are difficult to detect by their morphology on the seafloor. Young slides, not yet buried in pelagic and volcaniclastic sediments, have been described for Tenerife (Watts and Masson, 1995) and Hierro (Holcomb and Searle, 1991; Masson, 1996). The abundance of major landslide scars on both Tenerife and Gran Canaria (Fig. 12) requires the presence of corresponding deposits on the seafloor.

The huge basaltic volcanic lithic-rich debris-flow deposit in Hole $956 \mathrm{~B}$, with a minimum thickness of $80 \mathrm{~m}$, is interpreted to have resulted from collapse of the submarine and subaerial flanks of southwestern Gran Canaria, generating a debris avalanche and a probable tsunami that liberated abundant beach sands of exotic composition possibly from neighboring La Gomera, as discussed below.

This large landslide apparently occurred late in the period of active shield growth, when the volcano was close to its maximum size, young, and unstable, but not at the very end of the shield-building stage; this is shown by several lines of evidence:

1. The occurrence seaward of a major scar in southwestern Gran Canaria, the Horgazales Basin, which had formed before the very late-stage plagioclase-phyric trachybasalts of the shield (Schmincke, 1968). Landslides in Hawaiian volcanoes also occur characteristically during the late stage in their development (Moore et al., 1994);

2. The plagioclase-phyric, moderately evolved composition of hyaloclastite debris-flow deposits in the upper part of lithologic Unit V from Hole 956B;

3. The abundance of lithoclasts;

4. The presence of hummocky submarine topography, documented during Meteor cruise M24 (Funck and Schmincke, in press)

This interpretation has many ramifications and helps to further understand some hitherto unrecognized or unrelated aspects of the submarine and subaerial geology of Gran Canaria. Because of the magnitude of this event, turbidites that developed from the debris flow may have traveled long distances and may have reached the Madeira Abyssal Plain.

At Site 954, a 40-m-thick Miocene basaltic breccia and poorly recovered Pleistocene breccias are also interpreted as having resulted from flank collapse, whose generation may have been associated with collapse of the unstable upper part of the volcano encompassing the shallow submarine and subaerial parts. Two interpretations have been offered to explain the timing of this basaltic breccia. Funck and Lykke-Andersen (Chap. 2, this volume) trace this basaltic debrisflow deposit $70 \mathrm{~km}$ seaward, calculate a volume of $60 \mathrm{~km}^{3}$, and suggest that it has slid on top of, and thus covers, the stratigraphic interval between $\sim 14$ and $10.7 \mathrm{Ma}$, the latter being the age of the oldest sediment directly on top of the basaltic breccia. Schmincke, Weaver, Firth, et al. (1995) and Schmincke and Segschneider (Chap. 12, this volume) hold that the basaltic debris-flow deposit represents a slumped mass that was dislocated during the late basaltic shield stage before the inception of evolved volcanism of the Mogán and Fataga phases (i.e., before $14 \mathrm{Ma}$ ). The major evidence is that the massive breccia is entirely basaltic in composition, save for its nannofossil and foraminifer-bearing matrix. Since several hundred meters of ignimbrites and lava flows of the Mogán and Fataga Groups were deposited along the northern coast between 14 and $10 \mathrm{Ma}$, it would be extremely unlikely that a major landslide deposit forming a scar that extends subaerially would not be composed of a mixture of both shield basalts and overlying rhyolitic and, in particular, trachyphonolitic lava and ignimbrite fragments. The major stratigraphic gap of $\sim 3$ m.y. between the basaltic breccia and the lowermost overlying dated sediments is most likely caused by slumping of the interval representing the Fataga and Mogán volcaniclastic sediments and associated biogenic sediments. This is not inconsistent with especially abundant slumping in younger sediments of Hole 954B, as it is located at the site closest to the flank facies of Gran Canaria, which are characterized by more common slumping than the basin facies.

Coarse-grained lithified tuffs and lapillistones in Unit II at Hole 956B (158-195 mbsf; 3.5-4 Ma; Cores 157-956B-1R through 4R) are very poorly recovered, with core recovery in Cores $157-956 \mathrm{~B}-3 \mathrm{R}$ and $4 \mathrm{R}$ being only a few centimeters. In Schmincke, Weaver, Firth, et al. (1995), the large angular clasts, comprising basalt and trachyphonolitic ignimbrites identical petrographically to ignimbrites on Gran Canaria, were interpreted to be entirely of Miocene shieldbasalt composition with minor Miocene ignimbrite, suggesting that mass wasting (flank collapse), rather than volcanic activity, may have supplied the clasts. Because many basalt clasts and the matrix contain brown kaersutitic amphibole that is characteristic of Roque Nublo lavas, these deposits are here interpreted as representing the extremely widespread Roque Nublo debris-avalanche deposits that appear as widespread reflector in most of the volcanic apron. They are correlated with similar coarse-grained and poorly recovered sediments at Holes 954B and 953C, as described above.

\section{Tsunami Deposits}

The recognition of the tsunami deposit at Hole 956B, whose interpretation is still tentative, has major hazard implications. Tsunami deposits have been recognized at several 100 masl on Lanai (Moore and Moore, 1988). Pleistocene flank collapse and resulting slump and debris-flow deposits on Hierro and Tenerife have propagated toward the open sea (Fig. 12). Any large flank collapse of the eastern flank of the islands of La Palma and Hierro, however, is likely to generate tsunamis whose impact on the central islands could be severe.

Tsunamis are also thought to have been produced when voluminous pyroclastic flows entered the sea and washed beach sands derived from syenitic and mafic plutonics from the neighboring islands of La Gomera and, possibly, Fuerteventura into the depositional basin. Waves are thought to have propagated onto the surfaces of the hot ignimbrites, resulting in quenching and steam explosions. Both processes may have been instrumental in generating the large mass of glassy clasts that dominate many of the sand- to small lapilli-sized, thick turbidite and grain-flow deposits at Holes 953C, 955A, and 956B.

\section{Deposits Controlled by Climate, Sea-Level Changes, and Erosion}

Erosion throughout the evolution of Gran Canaria occurred at vastly different rates depending chiefly on climate, the physical nature of the substrate, the height of the volcanic edifices, and the orientation of the wind-exposed flanks of the island. High erosion and sedimentation rates are relatively easy to correlate with periods of major pyroclastic activity (Fig. 13). It is not yet possible to disentangle the role of climate change vs. exposure to dominant wind systems (i.e., the striking contrast between the wet north-northeastern side of 


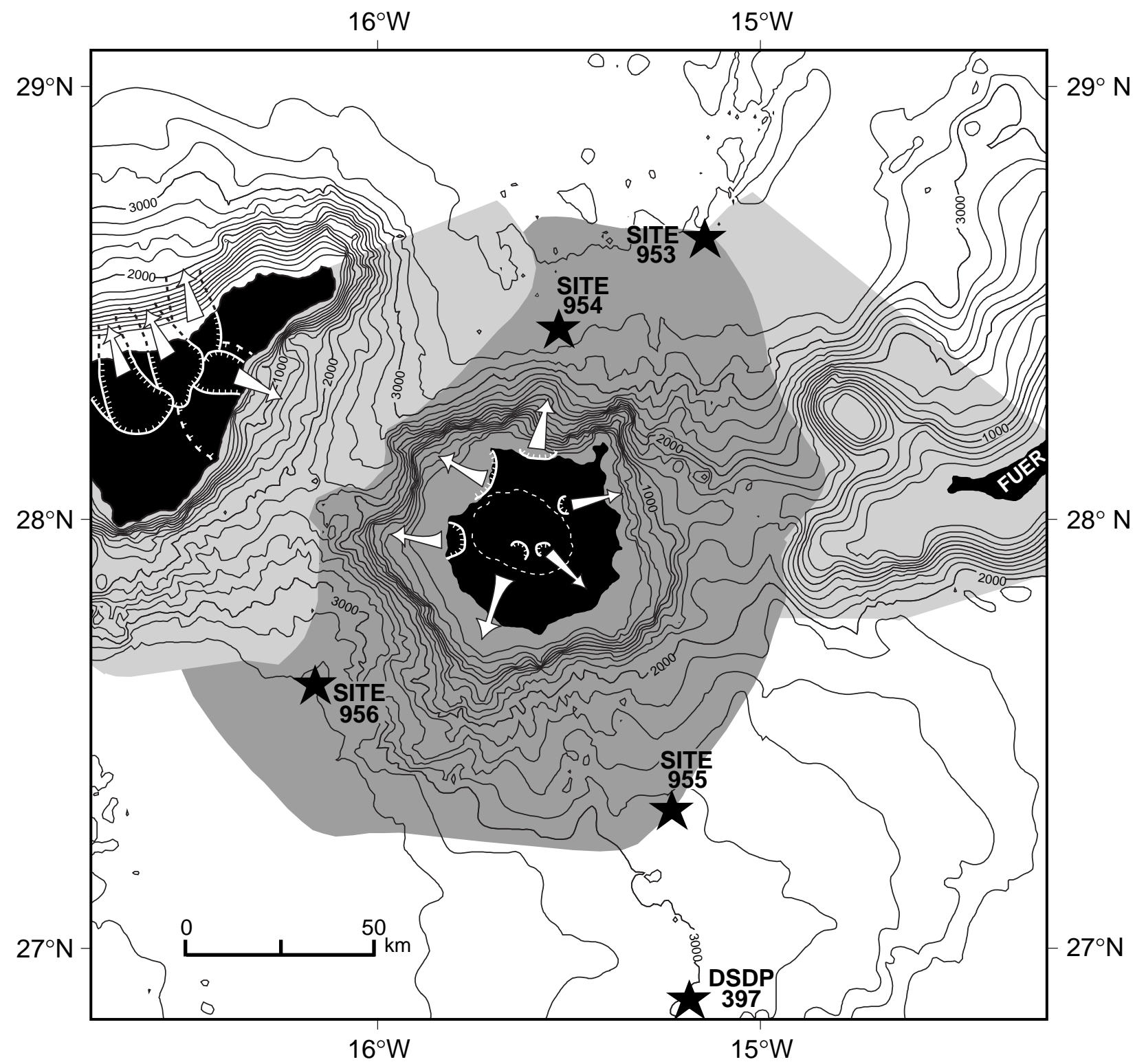

Figure 12. Gran Canaria and parts of Fuerteventura and Tenerife and their seismically defined shingled flanks (lower volcanic apron), which decrease in age from east to west after Funck et al. (1996). Amphitheaters of major landslides on Tenerife (after J. Navarro, unpubl. data) and Gran Canaria (scars) and main pathways of debris avalanches (white arrows). On Gran Canaria, the scars in the interior are mostly formed during the Roque Nublo collapse events which produced major debris avalanches that spread across the apron.

the island and the dry south) throughout the entire evolution of Gran Canaria.

For example, erosion has been much stronger along the wet northern to eastern flanks of the island from the shield stage to the present, probably indicating constant trade-wind directions from the middle Miocene to the present. Not only are the shield basalts more strongly eroded, conglomerates and slumping of hot ignimbrites on steep slopes is common in the northeasternmost section of Mogán ignimbrites at Agüimes. This regional contrast is well illustrated by the numerous thin basaltic turbidites of lithologic Unit V (Hole 953C), which are interpreted chiefly as representing erosion of shield lavas and pyroclastics in northeastern Gran Canaria. This interpretation is strongly supported by the land evidence of thick epiclastic sediments between the deeply incised basalts and the covering ignimbrites. The presence of basaltic rock fragments and xenocrysts, chiefly the ubiq- uitous titanaugite within the felsic volcaniclastics of lithologic Unit IV at Hole $953 \mathrm{C}$ and also as layers of basaltic volcaniclastic sands, and the striking paucity of such xenoclasts at Holes 955A and 956B in deposits from the same stratigraphic interval strengthen this interpretation. The southern half of the island was gently sloping and practically undissected during eruption of ignimbrites between $\sim 14$ and $13 \mathrm{Ma}$, causing concentric sedimentation on the volcanic apron. Erosion of the highly welded ignimbrites on land was minimal during this time, most likely because the climate was dry in the middle Miocene, as also shown by the absence on land of conglomerates and traces of vegetation, and also because of the leeward orientation of southern Gran Canaria.

Site 953 was also a privileged site for sedimentation. Although this site is the farthest from Gran Canaria, its sediment thicknesses and accumulation rates are much higher than at the other sites. Most 


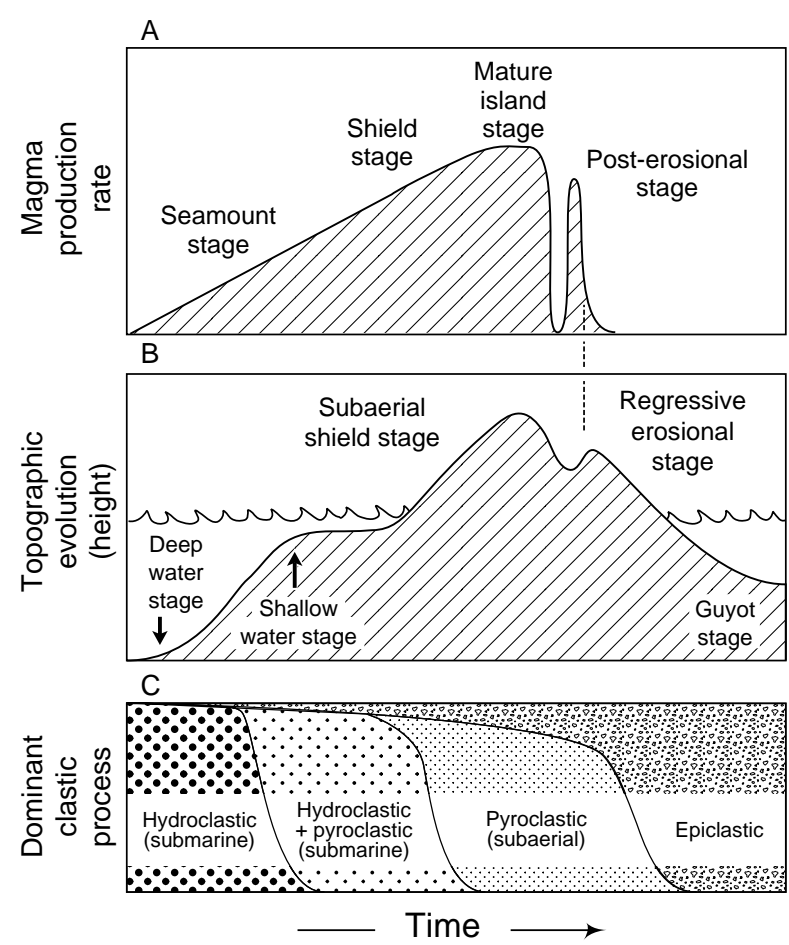

Figure 13. (A) Change of magma production rate, (B) topographic height, and $(\mathbf{C})$ dominant volcanic and clastic processes during the evolution of volcanic islands. The difference in gradient in (A) and (B) mainly results from the abundant production of volcaniclastic material during shallow submarine and initial subaerial shield stages (combination of hydroclastic and pyroclastic processes). Modified from Schmincke and Bogaard (1990).

likely, Site 953 was close to a major distribution channel down the submarine flanks of the island. Present-day canyons with maximum lengths of $25 \mathrm{~km}$ onshore can be traced down the submarine flanks of the island. Although the shelf area of Gran Canaria is only sparsely covered with bathymetric data, the shape and location of the subaerial canyons and their submarine counterparts allow a reasonable, though incomplete, correlation of the canyons into the sea (Funck and Schmincke, in press). The most prominent offshore continuation of a canyon is Barranco de Guiniguada in the northeast, which is connected to a 50-km-long submarine channel as much as $3.5 \mathrm{~km}$ wide and $200 \mathrm{~m}$ deep that terminates in the deep northern basin at a depth of $\sim 3500 \mathrm{~m}$, indicating significant submarine erosion by sediment mass flows debouching along the subaerial canyons into the sea.

No major volcaniclastic deposits of erosional origin or with a high proportion of xenoclasts were drilled during the nonvolcanic interval (lithologic Unit III) at Hole 953C, even though thicker volcaniclastic deposits would be expected to occur seaward of the main sediment pathways, down the submarine flanks of the volcano. The position of the main sediment distribution channels in the area around Site 953 may have migrated to the west or east during the late Miocene and Pliocene. Similarly, we interpret the small fraction of volcanic clasts in the 30-m-thick, dominantly biogenic section below syn-ignimbrite tephra Unit P1 at Hole 955A as being caused by this site's location outside major sediment distribution channels, which may also explain the thin felsic tephra layers in Unit IV at this hole.

Evidence for post-Miocene climate changes is based mostly on faunal evidence in calcareous sediments, indicating a major cooling at $\sim 2.75 \mathrm{Ma}$, with abundant oscillations between colder and warmer phases (Brunner and Maniscalco, Chap. 7, this volume). So far, these climate changes do not seem to be reflected in the nature and sedimentation rate of volcanic particles in the drilled cores. If present, regional climatic influences that are unrelated to erosional contrasts between wind- and leeward sides of the island may be masked by the overwhelming control of volcaniclastic sediment supply by direct explosive volcanic activity or by the availability of unconsolidated ash and lapilli deposits.

At Site 955, there is a sharp increase in the number of quartz-rich turbidites between 9.99 and 9.4 Ma. Goldstrand (Chap. 20, this volume), who studied the quartz-rich sediments chiefly at Sites 955 and 956, argues that turbidite generation on the African coast correlated with periods of sea-level lowstands. Quartz-rich turbidite deposits composed of well-rounded, very fine-grained sand were derived from Saharan eolian sands that migrated onto the subaerially exposed continental shelf and were shed into the deep-marine environment during falls in sea level. Shallow-marine bioclastics in foraminiferrich turbidites also correspond to periods of sea-level fluctuations. Large-scale submarine slumping appears to be more active during periods of intensified bottom currents and upwelling.

Triggering and transport of Pleistocene volcaniclastic sediments other than the fallout tephra deposits from Tenerife was, however, most likely caused by climatically controlled sea-level changes, although the detailed mechanisms are controversial.

\section{Slump Deposits}

Slump deposits are almost absent in the main volcaniclastic facies (lithologic Units VII to IV at all sites). Slumping of unconsolidated sediments younger than the volcaniclastic-dominated deposit (i.e., younger than $\sim 9 \mathrm{Ma}$ ), was most common in the slope facies at Site 954, closest to the island, especially in ooze sediments in the upper part of the holes where deposition was interrupted by hiatuses. Probable hiatuses at Site 954 are (1) lower Pliocene, 1-1.6 Ma; (2) lower Pliocene, 4.4-5.3 Ma; and (3) lower upper Miocene, 8.8-9.4 Ma. Two hiatuses of similar age were found at Site 955, where removal of the late Pliocene section and repetition of early Pliocene within the late Pliocene occurs within the slumped, chaotic facies of lithologic Subunit IA. At Site 955, all sediment of the upper $200 \mathrm{~m}$ is displaced with common reversals and hiatuses. Two hiatuses at Site 956 occur between 399 and 413 mbsf (8.8-9.4 Ma) and between 436 and 446 mbsf (10-10.8 Ma).

Slump deposits are almost restricted to post-Fataga deposits at all sites. Apparently, dominantly volcaniclastic sequences along the lower foot of the seamounts are more stable than dominantly or exclusively hemipelagic sediments and biogenic turbidites. The hiatuses between $\sim 8.8$ and 9.4 Ma at Sites 954, 955, and 956 are likely to have been caused by widespread distinct events, possibly related to volcano-tectonic activity. They coincide in time with the end of a phase of massive outpouring (possibly several $100 \mathrm{~m}$ in total thickness) of trachyphonolite lava flows and with the generation of two or three debris avalanches at the end of the Fataga phase on Gran Canaria; however, the exact mechanism by which the subsequent hiatuses were formed is unknown. Also, earthquakes or flank collapses that occurred during the growth of the submarine and major part of Tenerife probably at this time may have triggered the slumps. But, as noted by Goldstrand (Chap. 20, this volume), a major drop in global sea level at $\sim 10$ Ma may have influenced both sedimentation and slope sediment stability. For example, a fall in sea level caused by the onset of a glaciation would create excess pore pressure in the sediment column under impermeable or semipermeable layers. When the pressure gradient in the sediment columns is unable to equilibrate with the new hydrostatic pressures, failure is induced. Earthquakes will further enhance the failure potential of the sediments that are experiencing excess pore pressure. Large debris avalanches sourced on a volcanic island and emplaced on the seabed would set up excess pore pressures in the underlying sediment mass and may induce conditions suitable for failure (Roberts and Cramp, 1996).

Organic matter from terrestrial sources is also present in large amounts (Littke et al., Chap. 21, this volume) in sediments subjected to common slumping. The highest organic carbon concentrations were observed in intervals affected by mass or turbidity occurrence. Clear indications are the high Carbon Preference Index 5 values for 
$n$-alkanes and the microscopic data. This material may have been derived from higher land plants on the Canary Islands, although vascular plants at the coasts of Morocco and Mauretania may have provided material as well. The presence of resedimented organic matter derived from the erosion of older sedimentary rocks is documented by abundant inertinite and highly reflecting vitrinite and is attributed to erosion processes on the shore of northwest Africa. Site 955 experienced a higher supply of hydrogen-rich organic matter than Site 956, which is more distal from the continent. The rapid burial of organic matter in and under turbidite sediments at Site 955 inhibits strong aerobic microbial decay at the sediment/water interface and, therefore, enhances organic-matter preservation at this site.

\section{CONTRIBUTION OF NEIGHBORING ISLANDS TO THE VOLCANIC APRON OF GRAN CANARIA}

Before drilling, we were uncertain if the effects of volcanic detritus shed from adjacent islands into the basins would make it impossible to reconstruct the volcanic evolution of Gran Canaria from the sediments. Based on the sedimentary record of DSDP Leg 47A, we expected a possible contribution from Fuerteventura in the Miocene and a definite contribution of ash layers from Tenerife in the Pleistocene sediments.

There is some disagreement regarding the source of the basal hyaloclastites in Hole 953C (lithologic Unit VII). Funck and LykkeAndersen (Chap. 2, this volume) suggest that based on seismic evidence, the hyaloclastites of this unit may thicken to the east and may be derived from Fuerteventura. Schmincke and Segschneider (Chap. 12 , this volume) hold that the deposits may represent a deeper water facies of the Gran Canaria seamount, based on a lithologic change in the overlying hyaloclastites and breccias from poorly to highly vesicular (altered) sideromelane shards within Unit VII and continuing into Unit VI. If the hyaloclastites making up the 190-m-thick lithologic Unit VII in Hole 953C are indeed middle Miocene and not much older than $\sim 15$ or $16 \mathrm{Ma}$, this would support the suggestion (Schmincke, 1976) that the basaltic shield and at least the late seamount stage formed very rapidly and that high melt production occurred in the mantle beneath Gran Canaria during the shield stage.

There are additional reasons why the hyaloclastites of lithologic Unit VII from Site 953 could have been derived from Gran Canaria. We do not know whether a submarine seamount precursor phase to the Miocene subaerial basaltic shield phase lavas had ever developed in central Fuerteventura. For $\sim 40 \mathrm{~km}$ in the western half of Fuerteventura, the basement is made up of uplifted Mesozoic deepmarine sediments, Late Cretaceous to early Tertiary submarine volcanics, a major dike swarm, and several generations of plutons (Robertson and Bernoulli, 1982; Robertson and Stillman, 1979; LeBas et al., 1986; Stillman, 1987). The intrusive rocks of the basement complex are unconformably overlain by subaerial lavas of the Miocene shield phase. Although in some publications (e.g., Fuster et al., 1968) inference is made to the possible submarine nature of some Miocene shield lavas, no detailed evidence has been published, and we reserve judgment as to whether true submarine volcanic rocks-other than those of the basement complex and some Pliocene alkalic mafic lavas that advanced on a shallow marine platform- exist on the island. If the basement complex would extend at shallow crustal levels farther south and north from the present outcrop area, no thick true submarine hyaloclastites of the Miocene basaltic shield stage may have developed.

Even if the Amanay Bank, an unnamed eroded seamount south of Fuerteventura, and the southernmost volcanic shield complex of Fuerteventura, which make up the peninsula of Jandia, where available age dates are mostly between 14 and $17 \mathrm{Ma}$ (Coello et al., 1992), practically coeval with the shield of Gran Canaria, are underlain by a seamount succession - which we think is likely-we would have expected hyaloclastites representing shallow-water eruptions, emergent succession, and turbidites composed of products of subaerial erosion similar to those of lithologic Unit V at Site 953, rather than a deeper water facies, to have been supplied from these centers. Along this line of reasoning, the hyaloclastites of Unit V3 drilled during DSDP Leg 47A also could have been derived from Gran Canaria, rather than from Fuerteventura, as proposed originally (Schmincke and von Rad, 1979). In fact, the correlation of the debris-flow Units V3, V2, and V1, drilled during Leg 47A, with the hyaloclastite section at Site 953 is reasonable because these deposits occur biostratigraphically just below the nannoplankton Zone CN4/5 boundary, dated by Berggren et al. (1995) as 13.6 Ma, but may be as young as $13.4 \mathrm{Ma}$, based on the age of syn-ignimbrite turbidites (Sumita and Schmincke, Chap. 15 , this volume). A further argument for relating at least debris-flow deposit V1, but probably also V2 and V3, to Gran Canaria is the fact that they directly underlie rhyolitic tuffs correlated on chemical grounds with the upper Mogán ignimbrites.

Other evidence is equivocal. Lithologic Units VII and VI (Hole 953C) are separated by $\sim 3 \mathrm{~m}$ of nannofossil ooze mixed with volcanic particles in Sections 157-953C-83R-1 and 2 (966-969 mbsf), which may or may not represent a larger pause in volcaniclastic sedimentation. In any case, the pause represented by these mixed sediments is not long enough to postulate a source different from Gran Canaria. Conversely, the chemical similarity of the altered bulk hyaloclastites and the less strongly altered basalt clasts to the subaerial basalts on Gran Canaria does not necessarily imply the same source volcano, because significant compositional differences between the mildly alkalic basaltic shield volcanics of Gran Canaria and Fuerteventura have not yet been found.

K/Ar age determinations (Ancochea et al., 1990) and seismic data (Funck et al., 1996) indicate that the island of Tenerife is much younger than Gran Canaria, with the subaerial basaltic shield phase probably younger than $\sim 8 \mathrm{Ma}$. Contrary to our expectations, we did not recover any sediments at Site 956 southwest of Gran Canaria that are likely to represent the shield phase of Tenerife. The source of dark basaltic sandstone in Cores 157-956B-32R through 35R at Hole $956 \mathrm{~B}$ is still uncertain. Although our tentative interpretation is that they represent distal debris-flow-avalanche deposits from a subaerial stage of La Gomera, we cannot exclude Tenerife as a source. Minor mafic components in Pleistocene sediments at Site 956 are probably derived from Tenerife.

All trachytic-phonolitic ash layers younger than $2 \mathrm{Ma}$, however, are definitely sourced in Tenerife (Bogaard, Chap. 19; Rodehorst et al., Chap. 18; both this volume). Based on present evidence, felsic ash layers between 2.5 and 3 Ma could have been derived either from Tenerife or Gran Canaria.

The exotic sands in Core 157-956B-49R at Hole 956B are thought to have been derived most likely from La Gomera, with xenocrystic amphibole, mica, and some clinopyroxene occurring in stratigraphically higher hyaloclastite tuffs and lapillistones and in felsic volcaniclastic turbidites at Hole 956B.

The minor volumes of Pleistocene mafic volcaniclastics recovered at Hole 953A are unlikely to be derived from any island other than Gran Canaria because no voluminous volcanism is known in this age bracket from Fuerteventura or Lanzarote, and the distance to Tenerife appears to be too large.

\section{EVOLUTION OF SEDIMENTARY BASINS NORTH AND SOUTH OF GRAN CANARIA}

Two drilling strategies had to be weighed against each other when the drilling plans were developed. One strategy entailed drilling a radial transect through the apron to better understand the evolution of the entire system by analyzing changes from very proximal to distal facies. We decided against this approach because the entire geometry and internal structure of the apron were unknown at that time and because there was a high likelihood of significant differences between the sedimentary basins north and south of Gran Canaria. This assumption was based on the significant differences between the geo- 
logic history of northern and southern Gran Canaria during the Pliocene and Pleistocene and on the likelihood likely that the separation between a northern, here called Gran Canaria Basin, and southern basin (South Canary Channel) west of the eastern Canaries only began when Gran Canaria grew as a major island and continued with the growth of the western islands. One of the objectives of Leg 157 was, therefore, to record and contrast volcaniclastic and pelagic sedimentation in two different basins, both of which developed along with the successive emergence of the large volcanic islands of Gran Canaria and Tenerife from east to west, but which differed appreciably in their hinterland sediment supply areas (Fig. 14). Two drilling sites (Sites 953 and 954) were therefore placed in the northern basin, and two sites (Sites 955 and 956) were placed in the southern basin. The differences in volcanic and nonvolcanic sediments (i.e., basin history) between the two basins, which are more pronounced than had been anticipated, are reflected not only in the type of sediments but in the depositional and postdepositional processes as well.

Fossils in sediments interlayered with volcaniclastics in the subaerially exposed Fuerteventura basal complex suggest that volcanism on the easternmost islands may have begun as early as 70-80 m.y. ago (Le Bas et al., 1986). By 20 m.y. ago, Fuerteventura had experienced a very complex geologic history including major uplift of Mesozoic sediments, shallow submarine volcanism, and several periods of intrusion and erosion, followed by basaltic shield-building volcanism. The basin west of Fuerteventura was almost completely open to the south and west during this time, except for La Gomera whose oldest rocks are dated as more than $20 \mathrm{Ma}$ (Fig. 14). Fuerteventura and perhaps other parts of the long East Canary Ridge had thus formed a major morphological barrier long before Gran Canaria grew from the seafloor. Mass flows from the eastern Canaries were probably largely transported to the southwest, following the regional gradients.

Beginning with the growth of Gran Canaria around 16-15 m.y. ago, followed by Tenerife around 8 m.y. ago, and La Palma around 4 m.y. ago, slumps and sediment gravity flows shed to the west from the eastern Canaries and to the north from the central and western Canaries must have traveled west, the ultimate depot center for finegrained turbidites being the Madeira Abyssal Plain. The east-west migration of the Canaries is thus most likely the reason why volcanic turbidites in the Madeira Abyssal Plain are believed to be no older than about middle Miocene. Fuerteventura and Lanzarote, separated from each other by a narrow strait of only $40 \mathrm{~m}$ water depth (compared with $80 \mathrm{~m}$ for the Pleistocene-Holocene submarine abrasion platform) form the north-northeast-oriented East Canary Ridge, which includes Concepcion Bank, 150 km north-northeast of Lanzarote. The northern sites (953 and 954) are sheltered from sediment influx from the African continent behind this barrier, which existed before the growth of Gran Canaria.

Sarnthein (in Arthur et al., 1979) interpreted stained quartz in Pleistocene sediments at DSDP Site 397 to be of eolian origin. In contrast, Diester-Haas (1979) favored fluvial transport, followed by marine transport, of quartz. The near presence of silt- to sand-sized quartz at the northern Sites 953 and 954; its absence in the southern sites, where it occurs in thin millimeter- to centimeter-thick layers throughout several cores at Site 955; and its presence in coarser sediments at Site 956, although less pronounced than at Site 955 (Goldstrand, Chap. 20, this volume), suggest that the dominant mode of transport of quartz found at Sites 397, 955, and 956 was by bottom currents or sediment slides, rather than by wind, with the eastern barrier preventing influx into the area north of Gran Canaria.

At Site 955, green, organic-rich oozes are common, with the methane concentration ranging from 2000-40,000 ppm compared with 2-12 ppm at the other three sites. Although less common at Site 956 , these oozes are significantly more abundant than in the northern sites, which are shielded by the barrier from transport from upwelling areas along the African coast. Upwelling along the southeastern coast of Tenerife may also have generated organic-rich sediments at Site 956. Sediments at Sites 955 and 956 are also more enriched in organ-
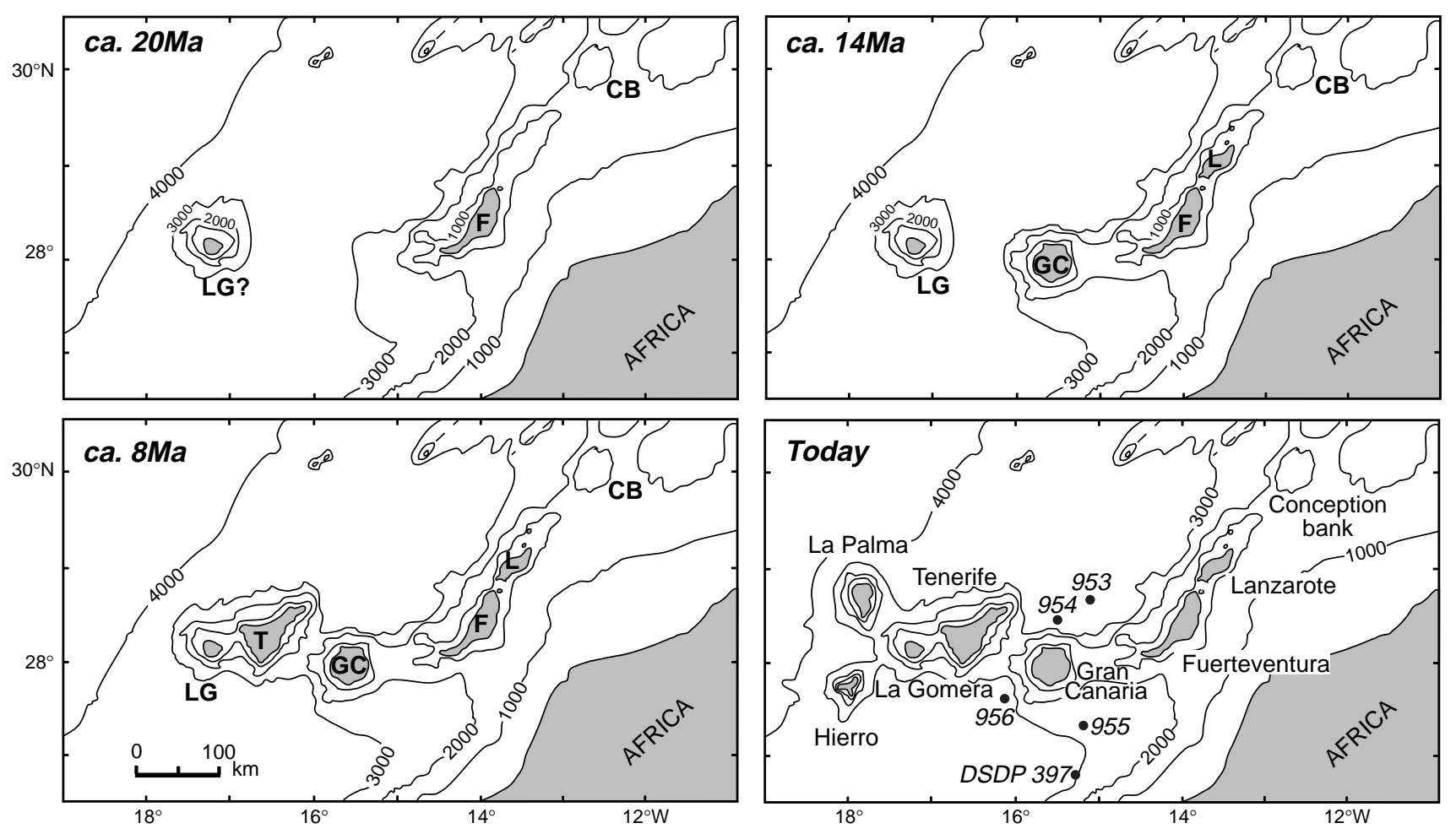

Figure 14. Four successive stages in the growth of the eastern, central, and western Canary Islands. The age of the plutonic complex on La Gomera is uncertain. Modified from Schmincke (1982). LG = La Gomera, $\mathrm{F}=$ Fuerteventura, $\mathrm{CB}=$ Conception Bank, GC = Gran Canaria, $\mathrm{L}=$ Lanzarote, and $\mathrm{T}=$ Tenerife. 
ic matter than the average deep-sea sediments. The strong contribution of marine organic matter is expressed in high percentages of marine liptinitic macerals, in the presence of hydrocarbon and fatty acids indicative of algal and bacterial organic matter, and in surprisingly high $\mathrm{HI}$ values. The sediments at Site 955 and, to a lesser extent, at Site 956 are also more clay-rich than those in the northern sites, as reflected in the lower carbonate contents of both pelagic and turbiditic sediments, indicating a significant contribution from the African continental margin by marine, rather than eolian, transport.

The only influx of sediments from Africa to the northern Site 953 may be the green, slightly organic-rich turbidites in Subunits IVB and IVC, which also contain minor quartz at their bases. The sediment ridge between Gran Canaria and Fuerteventura probably was much lower at that time, allowing episodic sediment mass flows to enter the basin north of Gran Canaria. No green, organic-rich turbidites were found at Site 954.

Because post-Miocene volcanic activity was practically absent in southern Gran Canaria, eroded products from the $>100 \mathrm{~km}^{3}$ Roque Nublo stratovolcano were largely channeled to the north and northeast, as also reflected on land by the thick Las Palmas clastic fan. Detritus from Pliocene-Pleistocene basanitic to nephelinitic flows occurs largely in biogenic deposits interspersed with fallout tephra layers from Tenerife. In the southern sites, Pliocene-Pleistocene mafic clasts are absent at Site 955 and are derived from Tenerife at Site 956.

\section{CONCLUSIONS}

The VICAP drilling project was the first systematic attempt to core a volcanic apron peripheral to an oceanic island. Its purpose was twofold: (1) to recover deposits whose analysis would allow a fairly precise reconstruction of the volcanic, compositional, and climatic evolution on land and to compare this model with the known geologic history of the island and the Canarian Archipelago in general and (2) to find deposits not exposed on land to reconstruct evolutionary processes hitherto unknown or only suspected. As a result of VICAP drilling, our understanding of the evolution of oceanic islands during the submarine to emergent stages has advanced along several lines, and several new ideas about fragmentation and transport mechanisms as well as growth patterns of ocean islands have emerged from the studies carried out so far.

In the lower to upper middle Miocene ( 16-9 Ma), about one-half of the deposits drilled $(750 \mathrm{~m}$ at Site $953,120 \mathrm{~m}$ at Site $955,300 \mathrm{~m}$ at Site 956) are entirely or dominantly volcaniclastic, and minor amounts of volcanic particles occur in most interbedded hemipelagic nannofossil and foraminifer oozes and chalks. Sedimentation rates are generally between 40 and $70 \mathrm{~m} / \mathrm{m}$.y., may exceed $100 \mathrm{~m} / \mathrm{m}$.y. in the dominantly volcaniclastic intervals of Units IV to VII at Site 953, and decrease to $\sim 20 \mathrm{~m} / \mathrm{m}$.y. during the nonvolcanic interval between $\sim 9$ and $6 \mathrm{Ma}$ (Brunner et al., Chap. 9, this volume). Basaltic volcaniclastic range from picritic through alkali basaltic and intermediate comprising the hyaloclastic and lithic volcaniclastic turbidites and debris-flow deposits (the lowermost $400 \mathrm{~m}$ in Hole $953 \mathrm{C}$ and lowermost $100 \mathrm{~m}$ in Hole 956B). The large thickness (450 $\mathrm{m}$ in Hole 953C, $150 \mathrm{~m}$ in Hole $956 \mathrm{~B}$, and $100 \mathrm{~m}$ in Hole $955 \mathrm{~A}$ ) of rhyolitic to trachyphonolitic turbidites and lesser contourites that reflect the eruption of several tens of ignimbrites and minor explosive fallout ashes from Gran Canaria is unusual for an ocean island setting.

If we had drilled closer to the island and as deep as at Site 953 (e.g., on the steep flanks of Gran Canaria), we probably would have intersected more pillow breccias and possibly intact pillow lava sections and dikes, but this would have been at the expense of the more complete and undeformed sections we encountered in the basin facies. Seismic constraints are insufficient to estimate the thickness of hyaloclastites below the bottom of the holes. We speculate that up to several hundred meters of hyaloclastites occur at greater depths at each site because those drilled are interpreted as representing the in- termediate- to shallow-water stage only. About 3000 to $4000 \mathrm{~m}$ of seamount evolution remains to be drilled.

A clear change has been recognized from moderately deep-water (>500 m?) hyaloclastites, characterized by poorly vesicular (altered) sideromelane shards through highly vesicular hyaloclastites formed in very shallow water from more evolved basaltic magmas (Hole 956B), to turbidite deposits interpreted as representing mainly subaerial erosion of the emergent older shield in northern Gran Canaria, which contrasts with a minor subaerial erosional stage in southwestern Gran Canaria (Fig. 15). The great thickness of rapidly produced hyaloclastites and debris flows, in which the two deepest holes bottomed, support the conclusion, based on shield-basalt dating, that the eruptive rate during this stage was high.

In Sites 953, 955, and 956 as much as $\sim 450 \mathrm{~m}$ of biogenic and volcaniclastic sediments that represent the Mogán and Fataga stratigraphic intervals played a fundamental role in controlling the lithostratigraphy of the apron sediments. In fact, the rhyolitic to basaltic ignimbrite $\mathrm{P} 1$, the initial ash-flow sheet that covered practically the entire shield volcano complexes on land and that represents the most important marker bed on the island, turned out to be the key horizon in the drilled sections as well. Because the island geology is so well known, even without knowing the age of the sediments in this stratigraphic interval, as determined by biostratigraphic and paleomagnetic data, a rough age assignment of major tephra layers, with an uncertainty in some cases of $<0.2 \mathrm{~m}$.y., could have been made based solely on stratigraphically diagnostic phenocrystic minerals, aided by glass and whole rock compositions.

What happens when hot ash flows enter the sea has been the subject of much controversy. The fact that between 14 and $\sim 9$ m.y. ago, as many as 50 ash flows entered the ocean around the shores of Gran Canaria-many of them being preserved as practically synchronous syn-ignimbrite tephra layers interbedded with increasingly epiclastic tuffaceous sediments-helps to answer some of the questions under discussion. The hot, dense ash flows became strongly welded, quenched, and fragmented by thermal shock and steam explosions, and collapsed ignimbrite mounds accumulated offshore before being transported as gravity flows into the surrounding sediment basins. Because of the high mass-entry rate of the ash flows into the sea, the piled-up flow units may have formed banks of welded tuff that stood above the water surface (depending on the distance to shore and the water depth to which the flows had advanced), but because of their glassy nature, they were fragmented quickly by brittle failure. Finegrained ashes elutriated during transport caused some crystal concentration in the bedload and formed dilute turbidite pulses, many of which may have outdistanced the coarser grained bedload.

Two long-standing problems concerning the existence of two or more shield volcanoes of different ages on the island and the dominance of the trade-wind directions from the Miocene to the present have now been solved by analyzing the Miocene basaltic and evolved volcaniclastic sediments northeast and southwest of Gran Canaria. Erosion throughout the history of the island has been much more severe on the northeastern side of the island, as reflected in the largely epiclastic nature of several hundred thin basaltic turbidites in the channelized, but voluminous, transport of syn-ignimbrite turbidites along subaerial and probably submarine channels and in the much higher abundance of basaltic xenoliths and augite xenocrysts in the evolved volcaniclastic deposits at Site 953. Shallow-water submarine volcanic activity was going on in the southwest almost until the inception of ignimbritic activity. We infer a concentric, sheet-like dispersal for both the undissected subaerial and submarine slopes of southern Gran Canaria throughout the Mogán into the Fataga stratigraphic interval.

Fresh, mostly slightly to nonvesicular and blocky, moderately evolved to mafic sideromelane shards that occur dispersed in many felsic volcaniclastic layers that correlate chiefly to the Mogán Group indicate basaltic eruptions on the submarine slopes of Gran Canaria. Apparently, the basaltic magmas parental to the more than $1000 \mathrm{~km}^{3}$ 


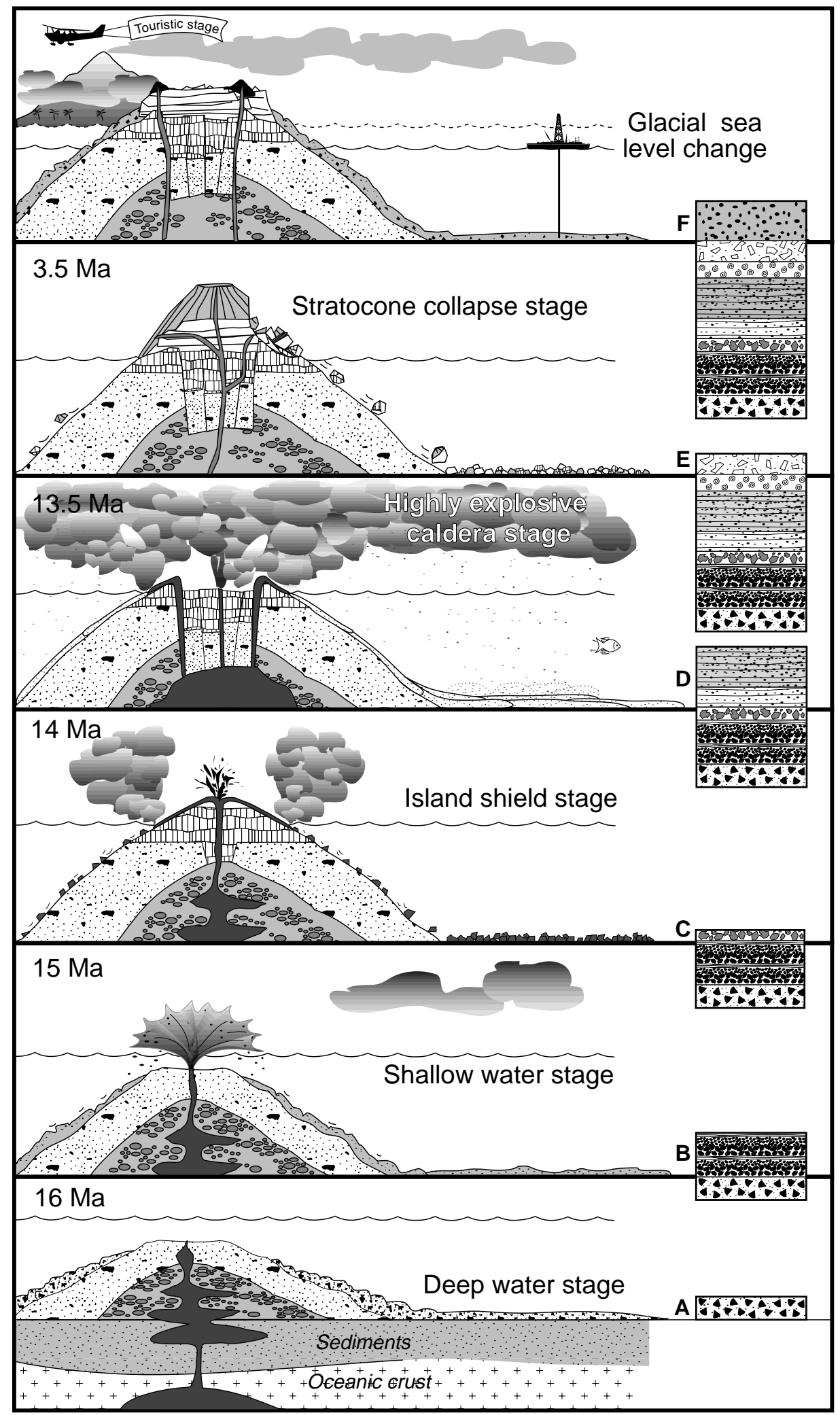

Figure 15. Schematic growth stages of Gran Canaria as reflected in the main types of volcaniclastic rocks drilled during Leg 157 . Volcaniclastic sediments produced during stage A are chiefly hyaloclastite debris-flow deposits, dominated by increasingly vesicular sideromelane shards during stage B, whereas lava delta breccias and epiclastic turbidites are common in the sediments of emergent stage C. Syn-ignimbritic and epiclastic rhyolitic, trachytic and trachyphonolitic turbidites and contourites are produced during ash flow eruptions and erosional intervals during stage $\mathrm{D}$, and widespread debris avalanche deposits resulting from stratocone collapse are characteristic of the coarse-grained, poorly recovered breccias correlated with the Roque Nublo volcanic phase (stage E). Glacially governed sea-level changes result in episodic beach sand transport to the depositional basin during the Quaternary (stage F), which is also characterized by abundant ash layers from the Cañadas/Teide volcanic complex on Tenerife. 
of rhyolite to trachyphonolites on the island were unable to erupt through the low-density magmas in the central reservoir, but caused moderate to deep submarine eruptions practically synchronously with felsic ash flow eruptions from the subaerial caldera.

Poorly recovered, coarse-grained lapillistones and breccias at $\sim 3.5 \mathrm{Ma}$ at Sites 953, 954, and 956 are interpreted as reflecting debris avalanches generated by collapse of the subaerial Roque Nublo stratocone that entered the sea north and south of the island. The lapillistones coincide with the most widespread seismic reflector in the volcaniclastic apron north and south of the island. The volcanic turbidites in the Madeira Abyssal Plain may, therefore, reflect major masswasting events of the Canary Islands.

The volcaniclastic components of the clastic apron of Gran Canaria are almost entirely composed of material derived from the island itself. This is largely attributed to the fact that the volcaniclastic fraction in the sediments at all holes above the shield phase is dominated in volume by the products of the Miocene explosive felsic volcanism.

Abundant, but volumetrically minor, phonolitic to trachytic fallout ashes in the Pleistocene sections in Holes 953A, 954A, and 956A show that the explosive history of the Cañadas/Teide volcano on Tenerife during the past $3 \mathrm{~m}$.y. was much more frequent and continuous than that inferred from the incomplete land record.

The submarine growth of the Gran Canaria seamount between $\sim 16$ and $14 \mathrm{Ma}$ initiated the subdivision of the open sea west of the East Canary Ridge into a basin north of Gran Canaria and the South Canary Channel south of the island, a morphological subdivision firmly established by the subsequent westward propagation of the island chain during later growth of the islands of Tenerife (at $~ 8 \mathrm{Ma}$ ) and La Palma (at $\sim 3 \mathrm{Ma}$ ). As a result, sediment pathways changed drastically. The northern basin received virtually no quartz-rich, organic material from the African mainland, with the coastal upwelling area sediments being transported down the South Canary Channel, whereas sediment pathways from the Canaries to the Madeira Abyssal Plain were established in the northern sediment basin. Quartz-rich turbidites in the southern sites appear to correlate with periods of lowered sea level, suggesting episodic shelf exposure on the coast of northwest Africa.

Returning to the questions asked at the beginning of this section regarding the expected (predicted) and unexpected (not predicted) findings, we can say that the two types of findings may balance out. Although the basic lithostratigraphy at all sites was predicted, the facies variations of all rock types was much greater than we expected. Consequently, our understanding of the submarine and subaerial evolution of an oceanic island has increased. We hoped to drill through some pillow lavas, but we were surprised to encounter a flank collapse deposit associated with exotic tsunami deposits as well as a thick section of turbidites mainly representing the subaerial stage of the basaltic shield. The wide dispersal around the entire apron of several syn-ignimbrite turbidites, the large amount of fresh glassy fragments of welded tuffs, and the striking contrast in dispersal mechanism between the northern and southern basins were similarly unanticipated. Our previous volume estimates of many ignimbrites and also the widespread Pliocene Roque Nublo debris-avalanche deposits had to be more than doubled. We are now able to much better appreciate the importance of pyroclastic deposits and debris avalanches in governing the transfer of volcanic materials to the deep sea in contrast with the much-reduced production of volcanic particles during purely erosional mass wasting, even of towering volcanic edifices.

The drilling results, together with the high-resolution seismic data and the land record, allowed more realistic calculations of magma production rates, which will contribute to a better understanding of mantle dynamics. Drilling at the VICAP sites during Leg 157 has demonstrated that the evolution of a volcanic island can be reconstructed by examining the lithostratigraphy of volcaniclastic sediments deposited in adjacent marine basins. The evolution of the volcanic apron peripheral to Gran Canaria and the detailed correlation with the land record will also improve the assessment of the significance of volcaniclastic facies in ancient rock successions, their rela- tionship to the tempo of volcanic activity, and the past volcanic, petrologic, and plate tectonic environments of sedimentary basins adjacent to volcanic source regions.

\section{ACKNOWLEDGMENTS}

We owe a great debt to the crew of the JOIDES Resolution and to ODP crew for providing a most pleasant atmosphere during the many weeks of high-pressure work aboard ship. We thank our scientific colleagues with whom it was most enjoyable to cooperate and whose work has been partially summarized in this synthesis. The manuscript greatly benefited from the critical comments of Dave Clague and an anonymous reviewer. Our work was supported by grants Schm 250/ 47-1, 60-1, 2 from the Deutsche Forschungsgemeinschaft, which we gratefully acknowledge. Last but not least, we are grateful to those colleagues in the Lithosphere Panel and Planning Committee who maintained their support of the VICAP drilling proposal over the years.

\section{REFERENCES}

Abdel Monem, A., Watkins, N.D., and Gast, P.W., 1971. Potassium-argon ages, volcanic stratigraphy, and geomagnetic polarity history of the Canary Islands: Lanzarote, Fuerteventura, Gran Canaria, and La Gomera. Am. J. Sci., 271:490-521.

, 1972. Potassium-argon ages, volcanic stratigraphy, and geomagnetic polarity history of the Canary Islands: Tenerife; La Palma, and Hierro. Am. J.Sci., 272:805-825.

Ancochea, E., Fúster, J.M., Ibarrola, E., Cendrero, A., Coello, J., Hernán, F. Cantagrel, J.M., and Jamond, C., 1990. Volcanic evolution of the island of Tenerife (Canary Islands) in the light of new K-Ar data. J. Volcanol. Geotherm. Res., 44:231-249.

Ancochea, E., Hernán, F., Cendrero, A., Cantagrel, J.M., Fúster, J.M., Ibarrola, E., and Coello, J., 1994. Constructive and destructive episodes in the building of a young oceanic island, La Palma, Canary Islands, and genesis of the Caldera de Taburiente. J. Volcanol. Geotherm. Res., 60:243262.

Arthur, M.A., von Rad, U., Cornford, C., McCoy, F.W., and Sarnthein, M., 1979. Evolution and sedimentary history of the Cape Bojador continental margin, northwestern Africa. In von Rad, U., Ryan W.B.F., et al., Init. Repts. DSDP, 47 (Pt. 1): Washington (U.S. Govt. Printing Office), 773816.

Banda, E., Dañobeitia, J.J., Surinach, E., and Ansorge, J., 1981. Features of crustal structure under the Canary Islands. Earth Planet. Sci. Lett., 55:11-24.

Berggren, W.A., Hilgen, F.J., Langereis, C.G., Kent, D.V., Obradovich, J.D., Raffi, I., Raymo, M.E., and Shackleton, N.J., 1995. Late Neogene chronology: new perspectives in high-resolution stratigraphy. Geol. Soc. Am. Bull., 107:1272-1287.

Bogaard, P., Schmincke, H.-U., Freundt, A., Hall, C., and York, D., 1988. Eruption ages and magma supply rates during the Miocene evolution of Gran Canaria: single crystal ${ }^{40} \mathrm{Ar} /{ }^{39} \mathrm{Ar}$ laser ages. Naturwissenschaften, 75:616-617.

Bosshard, E., and Macfarlane, D.J., 1970. Crustal structure of the western Canary Islands from seismic refraction and gravity data. J. Geophys. Res., 75:4901-4918.

Brocher, T.M., and ten Brink, U.S., 1987. Variations in oceanic Layer 2 elastic velocities near Hawaii and their correlation to lithospheric flexure. $J$. Geophys. Res., 92:2647-2661.

Cantagrel, J.-M., Cendrero, A., Fúster, J.-M., Ibarrola, E., and Jamond, C., 1984. K-Ar-chronology of the volcanic eruptions in the Canarian Archipelago: Island of La Gomera. Bull. Volcanol., 47:597-609.

Clague, D.A., and Dalrymple, G.B., 1987. The Hawaiian-Emperor volcanic chain, Part I. Geologic evolution. In Decker, R.W., Wright, T.L., and Stauffer, P.H. (Eds.), Volcanism in Hawaii. Geol. Surv. Prof. Pap. U.S., 1350:5-54.

Coello, J., Cantagrel, J.-M., Hernín, F., Fúster, J.-M., Ibarrola, E., Ancochea, E., Casquet, C., Jamond, C., Díaz de Téran, J.-R., and Cendrero, A., 1992. Evolution of the eastern volcanic ridge of the Canary Island based on new K-Ar data. J. Volcanol. Geotherm. Res., 53:251-274.

Diester-Haass, L., 1979. DSDP Site 397: climatological, sedimentological, and oceanographic changes in the Neogene autochthonous sequence. In 
von Rad, U., Ryan, W.B.F., et al., Init. Repts. DSDP, 47: Washington (U.S. Govt. Printing Office) 647-670.

Féraud, G., Schmincke, H.-U., Lietz, J., Gastaud, J., Pritchard, G., and Bleil, U., 1981. New K/Ar ages, chemical analyses and magnetic data of rocks from the islands of Santa Maria (Azores), Porto Santo and Madeira (Madeira Archipelago) and Gran Canaria (Canary Islands). Bull. Volcanol., 44:359-375.

Fiske, R.S. and Simkin, T., 1983. Krakatau 1883: Washington (Smithsonian Inst. Press).

Freundt, A., and Schmincke, H.-U., 1992. Mixing of rhyolite, trachyte and basalt magma erupted from a vertically and laterally zoned reservoir, composite flow P1, Gran Canaria. Contrib. Mineral. Petrol., 112:1-19.

, 1995a. Eruption and emplacement of a basaltic welded ignimibrite during caldera formation on Gran Canaria. Bull. Volcanol., $56: 640-659$.

, 1995b. Petrogenesis of rhyolite-trachyte-basalt composite ignimbrite P1, Gran Canaria, Canary Islands. J. Geophys. Res., 100:455-474.

Funck, T., 1996. Structure of the volcanic apron north of Gran Canaria deduced from reflection seismic, bathymetric and borehole data [Ph.D. dissert.]. Univ. Kiel.

Funck, T., Dickmann, T., Rihm, R., Krastel, S., Lykke-Andersen, H., and Schmincke, H.-U., 1996. Reflection seismic investigations in the volcaniclastic apron of Gran Canaria and implications for its volcanic evolution. Geophys. J. Int., 125: 519-536.

Funck, T., and Schmincke, H.-U., in press. Growth and destruction of Gran Canaria deduced from seismic reflection and bathymetric data. J. Geophys. Res.

Fuster, J.M., Hernandez-Pacheco, A., Munoz, M., Badiola, E.R., and Cacho, L.G., 1968. Geology and volcanology of the Canary Islands, Gran Canaria. Internat. Symp. Volcanol., Tenerife, Sept. 1968. Inst. Lucas Mallada Spec. Pub., 1-243.

Garcia, M.O., and Meyerhoff Hull, D., 1994. Turbidites from giant Hawaiian landslides: results from Ocean Drilling Program Site 842. Geology, 22:159-162.

Gurenko, A.A., Hansteen, T.H., and Schmincke H.-U., 1996. Evolution of parental magmas of Miocene shield basalts of Gran Canaria (Canary Islands): constraints from crystal, melt and fluid inclusions in minerals. Contrib. Mineral. Petrol., 124:422-435.

Hinz, K., et al., 1982. Preliminary results from DSDP Leg 79 seaward of the Mazagan Plateau off Central Morocco. In von Rad, U., Hinz, K., et al. (Eds.), Geology of the Northwest African Continental Margin: New York (Springer Verlag), 23-33.

Hoernle, K., and Schmincke, H.-U., 1993a. The petrology of the tholeiites through melilite nephelinites on Gran Canaria, Canary Islands: crystal fractionation, accumulation, and depth of melting. J. Petrol., 34:573-578.

, 1993b. The role of partial melting in the 15-Ma geochemical evolution of Gran Canaria: a blob model for the Canary Hotspot. J. Petrol., 34:599-627.

Holcomb, R.T., and Searle, R.C., 1991. Large landslides from oceanic volcanoes. Mar. Geotechnol., 10:19-32.

Holik, J.S., Rabinowitz, P.D., and Austin, J.A., 1991. Effects of Canary Hot Spot volcanism on structure of oceanic crust off Morocco. J. Geophys. Res., 96:12039-12067.

Klitgord, K.D., and Schouten, H., 1986. Plate kinematics of the central Atlantic. In Vogt, P.R., and Tucholke, B.E. (Eds.), The Geology of North America (Vol. M): The Western North Atlantic Region. Geol. Soc. Am., 351-378.

Krastel, S., 1995. Hochauflösende reflexionsseismische Messungen im vulkaniklastischen Schuttfächer südwestlich Gran Canarias, 133 pp. (Diplomarbeit). Inst. Geophys., Christian-Albrechts-Univ., Kiel.

Le Bas, M.J., Rex, D.C., and Stillman, C.J., 1986. The early magmatic chronology of Fuerteventura, Canary Islands. Geol. Mag., 123:287-298.

Lietz, J., 1973. Fossile Piedmont-Schwemmfächer auf der Kanaren-Insel Gran Canaria und ihre Beziehung zur Lage des Meeresspiegels. Z. Geomorph. N. F., 18:105-120.

Lipman, P.W., Normark, W.R., Moore, J.G., Wilson, J.B., and Gutmacher, C.E., 1988. The giant submarine Alika debris slide, Mauna Loa, Hawaii. J. Geophys. Res., 93:4279-4299.

Macdonald, G.A., and Katsura, T., 1964. Chemical composition of Hawaiian lavas. J. Petrol., 5:82-133.

Marti, J., Mitjavila, J., and Araña, V., 1994. Stratigraphy, structure, age and origin of the Cañadas Caldera (Tenerife, Canary Islands). Geol. Mag., 31:715-727.
Masson, D.G., 1996. Catastrophic collapse of the volcanic island of Hierro $15 \mathrm{ka}$ ago and the history of landslides in the Canary Islands. Geology, 24:231-234.

McDougall, I., and Schmincke, H.-U., 1977. Geochronology of Gran Canaria, Canary Islands: age of shield-building volcanism and other magmatic phases. Bull. Volcanol., 40:1-21.

Mehl, K.W., 1993. Structure and emplacement of the Pliocene Roque Nublo debris avalanche deposit, Gran Canaria, Spain.[Ph.D. thesis]. Ruhr-Univ. Bochum.

Menard, H.W., 1956. Archipelagic aprons. AAPG Bull., 40:2195-2210.

Moore, G.W., and Moore, J.G., 1988. Large scale bedforms in bolder gravel produced by giant waves in Hawaii. Spec. Pap.-Geol. Soc. Am., 229:101-109.

Moore, J.G., 1970a. Relationship between subsidence and volcanic load, Hawaii. Bull. Volcanol., 34:562-576.

, 1970b. Water content of basalt erupted on the ocean floor. Contrib. Mineral. Petrol., 28:272-279.

Moore, J.G., and Clague, D.A., 1992. Volcano growth and evolution of the island of Hawaii. Geol. Soc. Am. Bull., 104:1471-1484.

Moore, J.G., Clague, D.A., Holcomb, R.T., Lipman, P.W., Normark, W.R., and Torresan, M.E., 1989. Prodigious submarine landslides on the Hawaiian Ridge. J. Geophys. Res., 94:17465-17484.

Moore, J.G., and Fiske, R.S., 1969. Volcanic substructure inferred from dredge samples and ocean-bottom photographs, Hawaii. Geol. Soc. Am. Bull., 80:1191-1201.

Moore, J.G., Normark, W.R., and Holcomb, R.T., 1994. Giant Hawaiian landslides. Аnnu. Rev. Earth Planet. Sci., 22:119-144.

Parsons, B., and Sclater, J.G., 1977. An analysis of the variation of ocean floor bathymetry and heat flow with age. J. Geophys. Res., 82:803-827.

Ranero, C.R., Torne, M., and Banda, E., 1995. Gravity and multichannel seismic reflection constraints on the lithospheric structure of the Canary Swell. Mar. Geophys. Res., 17:519-534.

Rees, B.A., Detrick, R.S., and Coakley, B.J., 1993. Seismic stratigraphy of the Hawaiian flexural moat. Geol. Soc. Am. Bull., 105:189-205.

Roberts, J.A., and Cramp, A., 1996. Sediment stability on the western flanks of the Canary Islands. Mar. Geol., 134:13-30.

Robertson, A.H.F., and Bernoulli, D., 1982. Stratigraphy, facies and significance of late Mesozoic and early Tertiary sedimentary rocks of Fuerteventura (Canary Islands) and Maio (Cape Verde Islands). In von Rad, U., Hinz, K. (Eds.), Geology of the Northwest African Continental Margin: Berlin (Springer-Verlag), 498-525.

Robertson, A.H.F., and Stillman, C.J., 1979. Submarine volcanic and associated sedimentary rocks of the Fuerteventura basal complex, Canary Islands. Geol. Mag., 116:203-214.

Roeser, H.A., 1982. Magnetic anomalies in the magnetic quiet zone off Morocco. In von Rad, U., Sarnthein, M., and Seibold, E. (Eds.), Geology of the Northwest African Continental Margin: Berlin (Springer), 61-68.

Schmincke, H.-U., 1967. Pliozäne, subtropische Vegetation auf Gran Canaria. Naturwissenchaften, 4:185-186.

, 1968. Faulting versus erosion and the reconstruction of the MidMiocene shield volcano of Gran Canaria. Geol. Mitt., 8:23-50.

, 1976. The geology of the Canary Islands. In Kunkel, G. (Ed.), Biogeography and Ecology in the Canary Islands: The Hague (W. Junk), 67-184.

1982. Volcanic and chemical evolution of the Canary Islands. In von Rad, U., Hinz, K., Sarnthein, M., and Seibold, E. (Eds.), Geology of the Northwest African Continental Margin: Berlin (Springer), 273-306. , 1993. Geological Field Guide: Gran Canaria (5th ed.): Kiel, Germany (Pluto Press).

, 1994. Geological Field Guide: Gran Canaria (6th ed.): Kiel, Germany (Pluto Press).

Schmincke, H.-U., and Bogaard, P.V.D., 1990. Tephra layers and tephra events. In Einsele, G., Ricken, W., and Seilacher, A. (Eds.), Cycles and Events in Stratigraphy: Berlin (Springer-Verlag), 392-429.

Schmincke, H.-U., and Rihm, R., 1994. Ozeanvulkan 1993, Cruise No. 24, 15 April-9 May 1993. METEOR-Berichte, Univ. Hamburg, 94-2.

Schmincke, H.-U., and Staudigel, H., 1976. Pillow lavas on central and eastern Atlantic Islands (La Palma, Gran Canaria, Porto Santo, Santa Maria). Bull. Soc. Geol. Fr., 18:871-883.

Schmincke, H.-U., and von Rad, U., 1979. Neogene evolution of Canary Island volcanism inferred from ash layers and volcaniclastic sandstones of DSDP Site 397 (Leg 47A). In von Rad, U., Ryan, W.B.F., et al., Init. 
Repts. DSDP, 47 (Pt. 1): Washington (U.S. Govt. Printing Office), 703725 .

Schmincke, H.-U., Weaver, P.P.E., Firth, J.V., et al., 1995. Proc. ODP, Init. Repts., 157: College Station, TX (Ocean Drilling Program).

Staudigel, H., and Schmincke, H.-U., 1984. The Pliocene seamount series of La Palma/Canary Islands. J. Geophys. Res., 89:11195-11215.

Stillman, C.J.A., 1987. A Canary Islands dyke swarm: implications for the formation of oceanic islands by extentional fissural volcanism. In Mafic Dyke Swarms, Hall, H.C., and Fahring, W.F. (Eds.). Pap.-Geol. Surv. Can., 34: 243-255.

von Rad, U., Ryan, W.B.F., et al., 1979. Init. Repts. DSDP, 47 (Pt. 1): Washington (U.S. Govt. Printing Office).

Watts, A.B., and Masson, D.G., 1995. A giant landslide on the north flank of Tenerife, Canary Islands. J. Geophys. Res., 100:24487-24498.

Watts, A.B., and ten Brink, U.S., 1989. Crustal structure, flexure, and subsidence history of the Hawaiian Islands. J. Geophys. Res., 94:10473-10500.
Wissmann, G., 1979. Cape Bojador slope, an example for potential pitfalls in seismic interpretation without the information of outer margin drilling. In von Rad, U., Ryan, W.B.F., et al., Init. Repts. DSDP, 47 (Pt. 1): Washington (U.S. Govt. Printing Office), 491-499.

Ye, S., Rihm, R., Dañobeitia, J.J., Canales J.P., and Gallart, J., in press. A crustal transect through the northern and northeastern part of the volcanic edifice of Gran Canaria. J. Geodynam.

Date of initial receipt: 9 January 1997

Date of acceptance: 19 June 1997

Ms 157SR-135

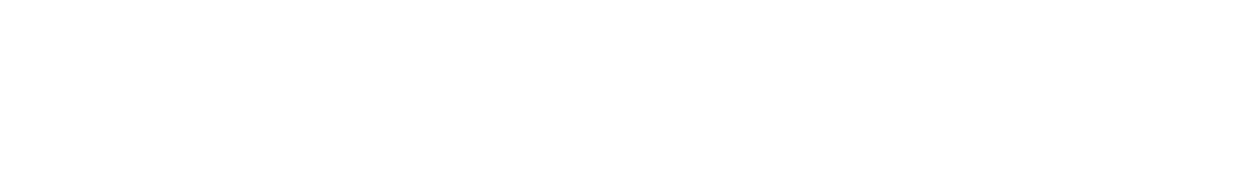

